\title{
Metal Sulfide Precipitation: Recent Breakthroughs and Future Outlooks
}

\author{
Humberto Estay ${ }^{1, *(D)}$, Lorena Barros ${ }^{1}$ and Elizabeth Troncoso ${ }^{2,3}$ (D) \\ 1 Advanced Mining Technology Center (AMTC), University of Chile, Santiago 8370451, Chile; \\ lorena.barros@amtc.cl \\ 2 Department of Chemistry, Universidad Tecnológica Metropolitana, Santiago 7800003, Chile; \\ elizabeth.troncoso@utem.cl \\ 3 Programa Institucional de Fomento a la Investigación, Desarrollo e Innovación (PIDi), \\ Universidad Tecnológica Metropolitana, Santiago 8940577, Chile \\ * Correspondence: humberto.estay@amtc.cl
}

Citation: Estay, H.; Barros, L.; Troncoso, E. Metal Sulfide Precipitation: Recent Breakthroughs and Future Outlooks. Minerals 2021, 11, 1385. https://doi.org/10.3390/ $\min 11121385$

Academic Editor: Yul Roh

Received: 15 November 2021

Accepted: 6 December 2021

Published: 8 December 2021

Publisher's Note: MDPI stays neutral with regard to jurisdictional claims in published maps and institutional affiliations.

Copyright: (c) 2021 by the authors. Licensee MDPI, Basel, Switzerland. This article is an open access article distributed under the terms and conditions of the Creative Commons Attribution (CC BY) license (https:// creativecommons.org/licenses/by/ $4.0 /)$.

\begin{abstract}
The interest in metal sulfide precipitation has recently increased given its capacity to efficiently recover several metals and metalloids from different aqueous sources, including wastewaters and hydrometallurgical solutions. This article reviews recent studies about metal sulfide precipitation, considering that the most relevant review article on the topic was published in 2010. Thus, our review emphasizes and focuses on the overall process and its main unit operations. This study follows the flow diagram definition, discussing the recent progress in the application of this process on different aqueous matrices to recover/remove diverse metals/metalloids from them, in addition to kinetic reaction and reactor types, different sulfide sources, precipitate behavior, improvements in solid-liquid separation, and future perspectives. The features included in this review are: operational conditions in terms of $\mathrm{pH}$ and $\mathrm{Eh}$ to perform a selective recovery of different metals contained in an aqueous source, the aggregation/colloidal behavior of precipitates, new materials for controlling sulfide release, and novel solid-liquid separation processes based on membrane filtration. It is therefore relevant that the direct production of nanoparticles (Nps) from this method could potentially become a future research approach with important implications on unit operations, which could possibly expand to several applications.
\end{abstract}

Keywords: metal sulfide precipitation; critical metals; precipitates; AMD; metal recovery; wastewater treatment

\section{Introduction}

Metal sulfide precipitation is studied because it is a process that is applied to recover or remove metals and metalloids from industrial effluents or hydrometallurgical leachates. This process uses a sulfide source, typically $\mathrm{H}_{2} \mathrm{~S}, \mathrm{Na}_{2} \mathrm{~S}, \mathrm{CaS},\left(\mathrm{NH}_{4}\right)_{2} \mathrm{~S}$, or NaHS to react with a cation contained in an aqueous solution, according to the reaction mechanism described in Equations (1)-(4) [1]. Metal sulfides have low solubility (Table 1) with respect to other precipitates such as hydroxides [2]. This characteristic is very attractive for environmental purposes, particularly when a dangerous heavy metal is removed and disposed of safely, because it is less likely to be leached in a wide $\mathrm{pH}$ range. In addition, a high $\mathrm{pK}_{\mathrm{sp}}$ value translates into a favorable tendency for Equations (3)-(4) to form products, showing a high conversion and, consequently, an efficient precipitation process.

Metal sulfide precipitation is naturally appealing for research, which can include the removal of potentially toxic elements (metals and metalloids) from industrial effluents, such as acid mine drainage (AMD) or copper smelter wastewater, and for recovering valuable metals from leachates of hydrometallurgical plants treating ores, wastes, or 
tailings. Likewise, the application of this method has improved for different metals, such as copper, cobalt, and nickel or metalloids such as arsenic.

$$
\begin{gathered}
\mathrm{H}_{2} \mathrm{~S} \rightleftarrows \mathrm{HS}^{-}+\mathrm{H}^{+}, \mathrm{pK}_{1}=6.99 \\
\mathrm{HS}^{-} \rightleftarrows \mathrm{S}^{2-}+\mathrm{H}^{+}, \mathrm{pK}_{2}=17.40 \\
\mathrm{M}^{2+}+\mathrm{S}^{2-} \rightleftarrows \mathrm{MS}(\mathrm{s}) \\
\mathrm{M}^{2+}+\mathrm{HS}^{-} \rightleftarrows \mathrm{MS}(\mathrm{s})+\mathrm{H}^{+}
\end{gathered}
$$

Table 1. Solubility products $\left(\mathrm{pK}_{\mathrm{sp}}\right)$ at $25^{\circ} \mathrm{C}$ for selected elements. Adapted from [2].

\begin{tabular}{cc}
\hline Element & pK \\
\hline $\mathrm{Bi}^{3+}$ & 98.8 \\
$\mathrm{Hg}^{2+}$ & 52.2 \\
$\mathrm{Ag}^{+}$ & 49.2 \\
$\mathrm{Cu}^{+}$ & 47.7 \\
$\mathrm{Cu}^{2+}$ & 35.9 \\
$\mathrm{Cd}^{2+}$ & 28.9 \\
$\mathrm{~Pb}^{2+}$ & 28.1 \\
$\mathrm{Sn}^{2+}$ & 27.5 \\
$\mathrm{Zn}^{2+}$ & 24.5 \\
$\mathrm{Co}^{2+}$ & 22.1 \\
$\mathrm{Ni}^{2+}$ & 21.0 \\
$\mathrm{Fe}^{2+}$ & 18.8 \\
$\mathrm{Mn}^{2+}$ & 13.3 \\
\hline
\end{tabular}

In 2010, a crucial review article published by Alison E. Lewis [1] consolidated the background and improvements in the field. From that date onward, studies on metal sulfide precipitation have expanded to different applications, and the number of articles related to the precipitate characteristics and solid-liquid separation improvements have also increased. Moreover, there is more industrial experience of sulfide precipitation-based processes in the last decade, particularly considering the SART (Sulfidization, Acidification, Recycling, and Thickening) process, which recovers copper and cyanide from cyanide leachates solution in gold cyanidation [3], and the copper recovery from Acid Mine Drainages (AMD) [4].

In order to provide a historical perspective on the development of research on the topic, the Scopus (Elsevier) database was used to carry out a scientometric analysis of the literature related to the terms 'metal sulphide precipitation' and 'metal sulfide precipitation' in the research field topic (date exported: 21 July 2021). Consequently, these terms were searched as text word in the title, abstract, and/or keywords of the documents. The results were restricted for articles, reviews, and conference papers. The time span used to evaluate the distribution of the scientific production was from 1935 to 2021. Following that, a detailed analysis of their abstracts was carried out in order to identify those documents directly focusing on metal sulfide precipitation processes, excluding articles related to geochemistry. Then, a set of 140 documents was built. Documents published between 2000 and $2021(n=131)$ were considered to apply the scientometric analysis based on documents by: year, year by source ( $>4$ documents), country/territory (top 10), and subject area (Figure 1). 


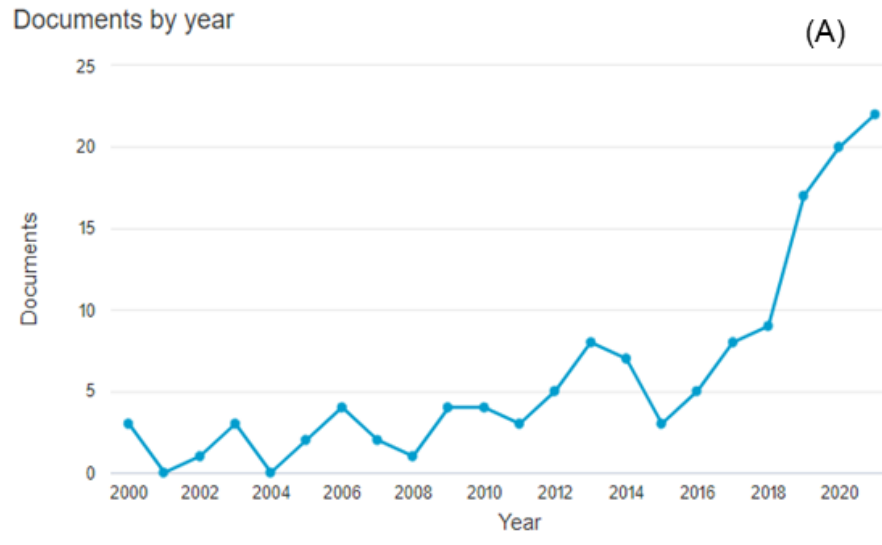

Documents per year by source

(B)

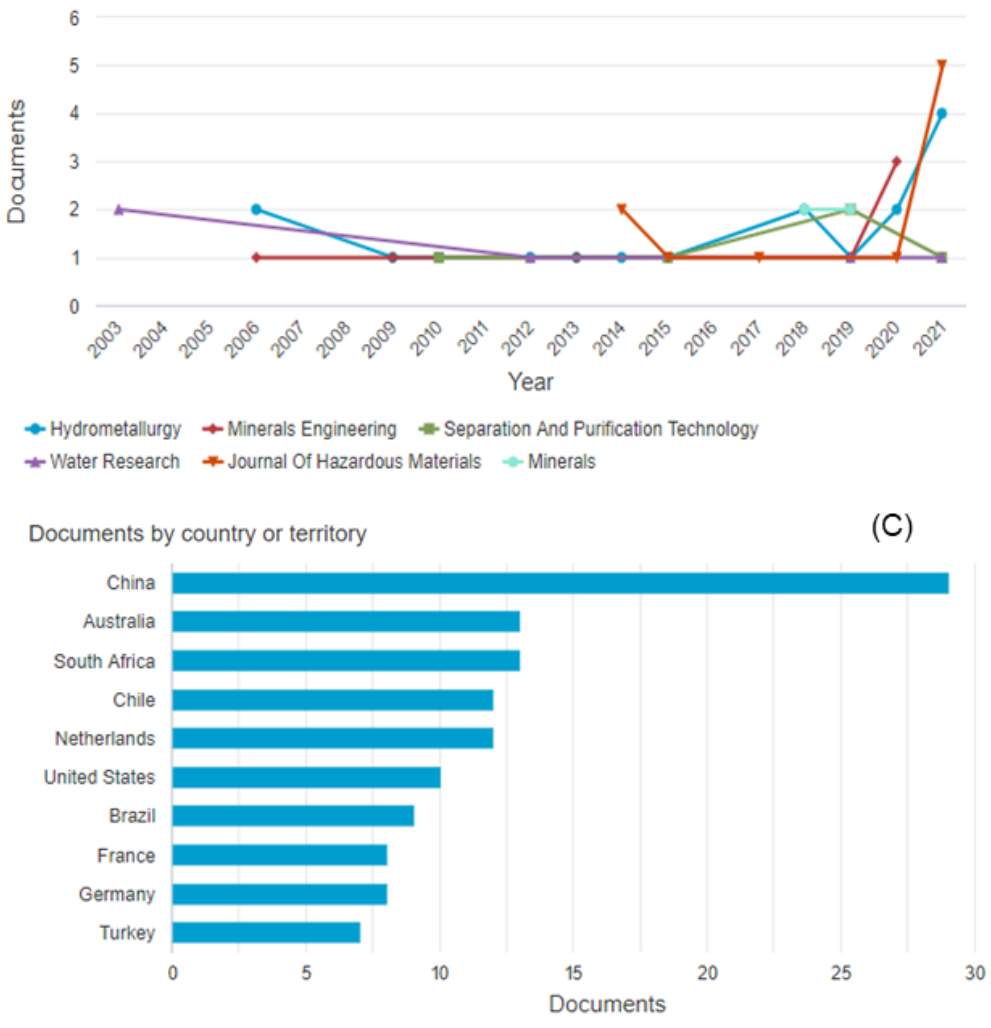

Documents by subject area

(D)

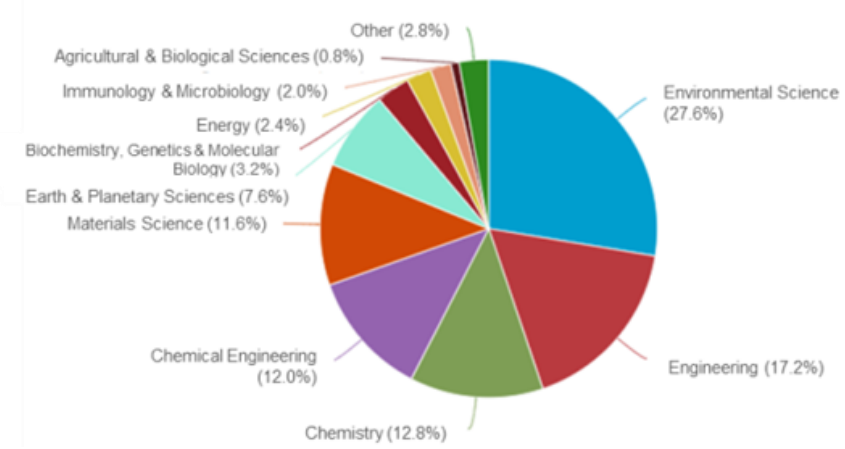

Figure 1. Results from the scientometric analysis, period 2000-2021. (A) Documents per year, (B) Documents by source (journal), (C) Documents by the top 10 countries, and (D) Documents by subject area. 
According to Figure 1, the scholarly output per year has significantly increased since 2017 (Figure 1A), where the subject area "environmental science" contained most of the articles published ( 28\%) (Figure 1D). In particular, China was the country with the most documents published between 2000-2021 (Figure 1C). This analysis shows that the metal sulfide precipitation method has gained interest for environmental studies, but also for engineering areas ( 17\%). The topic has also gained interest by journals related to extractive metallurgy (Figure 1B). The current challenges of residue treatment, such as circular economy and process optimization, will probably trigger more interest in developing technology on this matter.

This article describes the breakthroughs conducted on metal sulfide precipitation since the review article published by Lewis in 2010 [1], emphasizing the point of view in process engineering. By this, the structure of this manuscript is based on the general flow diagram of a typical metal sulfide precipitation process as shown in Figure 2.

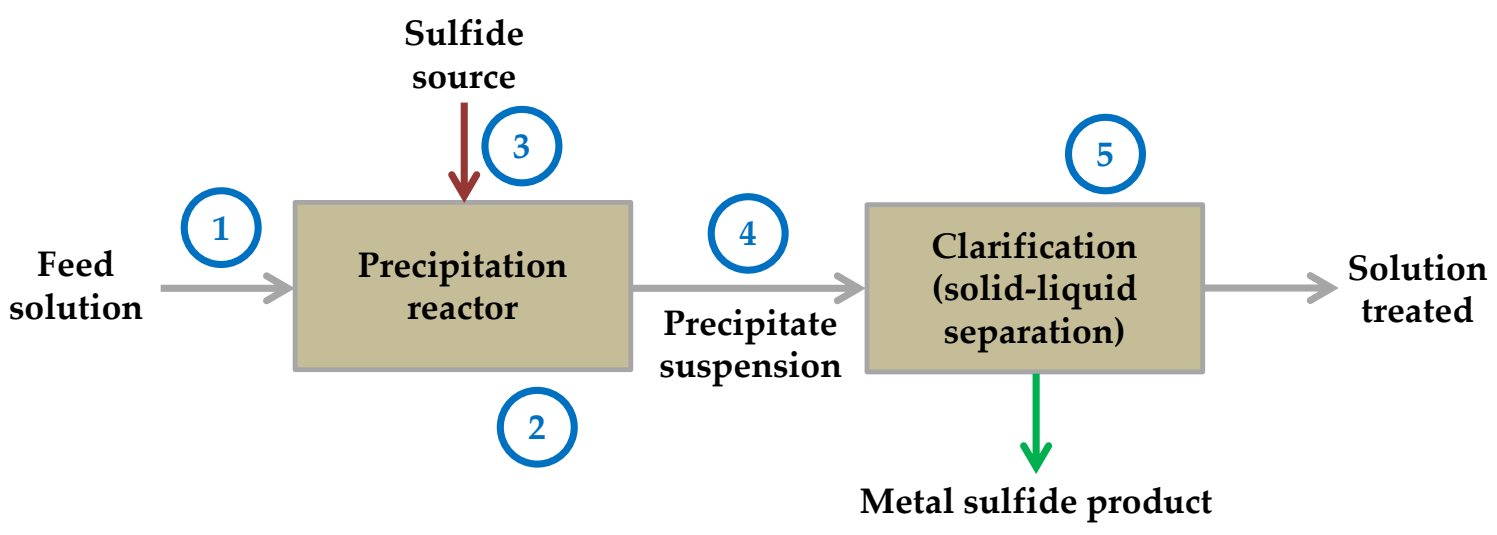

Figure 2. Schematic representation of the flow diagram of a typical metal sulfide precipitation process. Numbers are related to the focus of the studies reviewed here.

Figure 2 contains numbers that represent the different areas or topics studied in the articles reviewed and discussed in this work. Thus, the structure of this review is based on the flow diagram of the metal sulfide precipitation process, with an emphasis on the findings and challenges of the following issues:

- Applications for recovering and removing metals and metalloids from different sources (feed solution);

- Aspects regarding chemical reactions and reactor design (precipitation reactor);

- Sulfide reagent sources (sulfide sources);

- Characteristics of precipitates (precipitate suspension);

- Advances in solid-liquid separation (clarification);

- Future perspectives.

\section{Applications for Recovering and Removing Metals and Metalloids from Different Sources}

The metal sulfide precipitation process can be applied to different aqueous feed solutions to recover or remove some elements of interest (Figure 2). The application of metal sulfide precipitation is significantly wide for diverse elements, such as those listed in Table 1, and their content in different aqueous solutions.

In this context, the use of metal sulfide precipitation is still one of the most common treatments to remove metals from AMD. This is particularly true for the synergic possibility to generate a sulfide source given the action of a sulfate-reducing bacteria from the sulfate contained in the same AMD. Furthermore, it can also be seen in the application of leachate solutions from the hydrometallurgical treatment of ores, tailings, smelting waste, or even electronic waste. The latter has been widely studied for recovering different metals of 
interest and the removal of toxic metalloids in recent years. Consequently, the application of metal sulfide precipitation has been investigated to treat industrial effluents in general.

This section summarizes the most relevant studies found for the treatment of different aqueous solutions in recent years. Table 2 summarizes the most important results obtained for each study described below.

Table 2. Summary of applications for the metal sulfide precipitation process for different feed solutions and metals/metalloids.

\begin{tabular}{|c|c|c|c|c|c|c|}
\hline \multirow[b]{2}{*}{ Feed Solution Type } & \multirow[b]{2}{*}{ Metals/Metalloids } & \multicolumn{2}{|c|}{ Operational Conditions } & \multirow[b]{2}{*}{ Conversion, $\%$} & \multirow[b]{2}{*}{$\begin{array}{l}\text { Sulfide Reagent } \\
\text { Source }\end{array}$} & \multirow[b]{2}{*}{ Reference } \\
\hline & & $\mathrm{pH}$ & $\begin{array}{l}\text { Sulfide Dosage, } \\
\text { Molar Ratio } \\
\text { (S'-/M) }\end{array}$ & & & \\
\hline AMD & As & 4.0 & Not reported & $8-95.4$ & Biogenic $\mathrm{H}_{2} \mathrm{~S}$ & [5] \\
\hline AMD & As & $\sim 0$ & 3-5 & $\sim 100$ & $\mathrm{FeS}$ & [6] \\
\hline AMD & $\mathrm{Sb}$ & 7 & 15 & $\sim 100$ & Biogenic $\mathrm{H}_{2} \mathrm{~S}$ & [7] \\
\hline AMD & $\mathrm{Cu}$ & $2.34-2.56$ & Not reported & $10-80$ & Biogenic $\mathrm{H}_{2} \mathrm{~S}$ & [8] \\
\hline AMD & $\begin{array}{l}\mathrm{Cu} \\
\mathrm{Zn}\end{array}$ & $\begin{array}{l}3.7 \\
5.0\end{array}$ & Not reported & $\begin{array}{l}99.8 \\
99.9\end{array}$ & Biogenic $\mathrm{H}_{2} \mathrm{~S}$ & [9] \\
\hline AMD & $\begin{array}{l}\mathrm{Cu} \\
\mathrm{Zn}\end{array}$ & $\begin{array}{l}2.0 \\
3.0\end{array}$ & $\begin{array}{l}2.91 \\
3.84\end{array}$ & $\begin{array}{l}>95 \\
>95\end{array}$ & $\mathrm{Na}_{2} \mathrm{~S} 1 \mathrm{M}$ & [10] \\
\hline AMD & $\begin{array}{l}\mathrm{Cu} \\
\mathrm{Fe} \\
\mathrm{Zn} \\
\mathrm{Cu}\end{array}$ & 6.7 & Not reported & $\begin{array}{c}99.99 \\
87.64 \\
99.88 \\
>99.9\end{array}$ & Biogenic $\mathrm{H}_{2} \mathrm{~S}$ & [11] \\
\hline AMD & $\begin{array}{l}\mathrm{Pb} \\
\mathrm{Zn} \\
\mathrm{Cu} \\
\mathrm{Cd}\end{array}$ & 3.2 & Not reported & $\begin{array}{c}>99.9 \\
>99.9 \\
>90 \\
>90\end{array}$ & Biogenic $\mathrm{H}_{2} \mathrm{~S}$ & [12] \\
\hline AMD & $\begin{array}{l}\mathrm{Pb} \\
\mathrm{Zn} \\
\mathrm{Fe} \\
\mathrm{Ni} \\
\mathrm{Cu}\end{array}$ & $3.0-7.0$ & Not reported & $\begin{array}{l}>90 \\
>90 \\
>88 \\
>82 \\
93.3\end{array}$ & Biogenic $\mathrm{H}_{2} \mathrm{~S}$ & [13] \\
\hline AMD & $\begin{array}{l}\mathrm{Fe} \\
\mathrm{Zn}\end{array}$ & 4.0 & Not reported & $\begin{array}{c}99.2 \\
\sim 100\end{array}$ & Biogenic $\mathrm{H}_{2} \mathrm{~S}$ & [14] \\
\hline AMD & $\mathrm{Cu}$ & 2.2 & Not reported & 99 & Biogenic $\mathrm{H}_{2} \mathrm{~S}$ & [15] \\
\hline AMD & $\begin{array}{l}\mathrm{Cu} \\
\mathrm{Zn} \\
\mathrm{Cu}\end{array}$ & $\begin{array}{l}2.0-6.0 \\
3.0-8.0\end{array}$ & $\begin{array}{l}0.5-1.5 \\
0.5-1.5\end{array}$ & $\begin{array}{c}80.0-97.9 \\
57.5-99.95 \\
>99\end{array}$ & $\mathrm{Na}_{2} \mathrm{~S}$ solution & [16] \\
\hline AMD & $\begin{array}{l}\mathrm{Fe} \\
\mathrm{Zn}\end{array}$ & 4.0 & Not reported & $\begin{array}{l}>99 \\
>99\end{array}$ & Biogenic $\mathrm{H}_{2} \mathrm{~S}$ & [17] \\
\hline AMD & $\begin{array}{l}\mathrm{Cu} \\
\mathrm{Zn} \\
\mathrm{Cu}\end{array}$ & $7.0-8.0$ & Not reported & $\begin{array}{l}>99 \\
>99 \\
70\end{array}$ & Biogenic $\mathrm{H}_{2} \mathrm{~S}$ & [18] \\
\hline AMD & $\begin{array}{l}\mathrm{Pb} \\
\mathrm{Zn} \\
\mathrm{Fe}\end{array}$ & 2.2 & Not reported & $\begin{array}{l}37 \\
79 \\
65\end{array}$ & Biogenic $\mathrm{H}_{2} \mathrm{~S}$ & [19] \\
\hline AMD & $\begin{array}{l}\mathrm{Cu} \\
\mathrm{Tl} \\
\mathrm{Cd}\end{array}$ & $1.7-3.3$ & $1.0-1.5$ & $\begin{array}{c}75-100 \\
>99 \\
>87\end{array}$ & $1 \mathrm{M} \mathrm{NaHS}$ solution & [20] \\
\hline Industrial wastewater & $\begin{array}{l}\mathrm{Pb} \\
\mathrm{Cu} \\
\mathrm{Zn}\end{array}$ & 12.0 & $>250$ & $\begin{array}{l}>40 \\
>94 \\
>67\end{array}$ & $1 \mathrm{~g} / \mathrm{L} \mathrm{Na}_{2} \mathrm{~S}$ solution & [21] \\
\hline Industrial wastewater & $\begin{array}{l}\mathrm{Cu} \\
\mathrm{Zn} \\
\mathrm{Cu}\end{array}$ & 4.0 & $\begin{array}{l}2.5 \\
2.3\end{array}$ & $\begin{array}{c}\sim 100 \\
60 \\
>99\end{array}$ & $\mathrm{NaHS}$ & [22] \\
\hline Industrial wastewater & $\begin{array}{l}\mathrm{Zn} \\
\mathrm{Ni}\end{array}$ & 7.0 & Not reported & $\begin{array}{l}>95 \\
>95\end{array}$ & Biogenic $\mathrm{H}_{2} \mathrm{~S}$ & [23] \\
\hline Industrial wastewater & $\begin{array}{l}\mathrm{Cu} \\
\mathrm{Cu}\end{array}$ & 7.5 & Not reported & $\begin{array}{l}\sim 100 \\
>99.5\end{array}$ & Biogenic $\mathrm{H}_{2} \mathrm{~S}$ & [24] \\
\hline Industrial wastewater & $\begin{array}{l}\mathrm{Zn} \\
\mathrm{Ni}\end{array}$ & $7.0-8.3$ & Not reported & $\begin{array}{l}>99 \\
>99\end{array}$ & Biogenic $\mathrm{H}_{2} \mathrm{~S}$ & [25] \\
\hline Industrial wastewater & As & $<1.0$ & 1.65 & $\sim 100$ & $\begin{array}{l}\mathrm{Na}_{2} \mathrm{~S} \text { wt. } 10 \% \\
\text { solution }\end{array}$ & [26] \\
\hline Industrial wastewater & $\begin{array}{l}\mathrm{Pd} \\
\mathrm{Fe}\end{array}$ & $\begin{array}{l}1.7 \\
2.3\end{array}$ & $\begin{array}{c}0.5-2.0 \\
0.6-3.75\end{array}$ & $\begin{array}{l}87.9-99.8 \\
53.8-98.3\end{array}$ & Biogenic $\mathrm{H}_{2} \mathrm{~S}$ & [27] \\
\hline
\end{tabular}


Table 2. Cont

\begin{tabular}{|c|c|c|c|c|c|c|}
\hline \multirow[b]{2}{*}{ Feed Solution Type } & \multirow[b]{2}{*}{ Metals/Metalloids } & \multicolumn{2}{|c|}{ Operational Conditions } & \multirow[b]{2}{*}{ Conversion, $\%$} & \multirow[b]{2}{*}{$\begin{array}{l}\text { Sulfide Reagent } \\
\text { Source }\end{array}$} & \multirow[b]{2}{*}{ Reference } \\
\hline & & $\mathrm{pH}$ & $\begin{array}{l}\text { Sulfide Dosage, } \\
\text { Molar Ratio } \\
\text { (S'-/M) }\end{array}$ & & & \\
\hline $\begin{array}{l}\text { Plating industrial } \\
\text { effluent }\end{array}$ & $\begin{array}{l}\mathrm{Cu} \\
\mathrm{Zn} \\
\mathrm{Cr}\end{array}$ & 10.0 & Not reported & $\begin{array}{c}93.9 \\
99.4 \\
99.99\end{array}$ & $\mathrm{Na}_{2} \mathrm{~S}$ & [28] \\
\hline & $\mathrm{Cu}$ & & Not reported & $>99$ & & \\
\hline $\begin{array}{l}\text { Plating industrial } \\
\text { effluent }\end{array}$ & $\begin{array}{l}\mathrm{Zn} \\
\mathrm{Ni} \\
\mathrm{Fe}\end{array}$ & 1.7 & 1.76 & $\begin{array}{c}85-97 \\
25-92 \\
2-99\end{array}$ & Biogenic $\mathrm{H}_{2} \mathrm{~S}$ & [29] \\
\hline $\begin{array}{l}\text { Plating industrial } \\
\text { effluent }\end{array}$ & $\begin{array}{l}\mathrm{Ni} \\
\mathrm{Zn} \\
\mathrm{Cu}\end{array}$ & $8-12$ & Not reported & $\begin{array}{l}65.8-95.3 \\
93.8 \\
100\end{array}$ & $\mathrm{Na}_{2} \mathrm{~S}$ solution & [30] \\
\hline $\begin{array}{c}\text { Cu-laden electroplating } \\
\text { effluent }\end{array}$ & $\mathrm{Cu}$ & $6.5-8.0$ & Not reported & 99.9 & Biogenic $\mathrm{H}_{2} \mathrm{~S}$ & [31] \\
\hline Co-Mo Catalyst leachate & $\begin{array}{l}\text { Mo } \\
\text { Co }\end{array}$ & $\begin{array}{l}\text { alkaline } \\
1.0\end{array}$ & $>1000$ & $\begin{array}{l}98.2 \\
98.0\end{array}$ & $\begin{array}{l}\mathrm{Na}_{2} \mathrm{~S} \text { wt. } 40 \% \\
\text { solution }\end{array}$ & [32] \\
\hline $\begin{array}{l}\text { Recycled mineral } \\
\text { sludge leachate }\end{array}$ & $\begin{array}{l}\mathrm{Mo} \\
\mathrm{Co} \\
\mathrm{Ni}\end{array}$ & 1.0 & 10 & $\begin{array}{l}40.0-95.0 \\
52.0-98.0 \\
48.0-98.0\end{array}$ & $1 \mathrm{M} \mathrm{Na}_{2} \mathrm{~S}$ solution & [33] \\
\hline Ni-Cd battery leachate & $\mathrm{Cd}$ & $0.2-1.4$ & $0.5-2.0$ & $\sim 100$ & $\mathrm{Na}_{2} \mathrm{~S}-\left(\mathrm{NH}_{4}\right)_{2} \mathrm{~S}-\mathrm{FeS}$ & [34] \\
\hline $\begin{array}{l}\text { Waste printed circuit } \\
\text { boards leachate }\end{array}$ & $\mathrm{Cu}$ & 10.6 & $1.0-1.2$ & $88-99.5$ & $5.2 \mathrm{M} \mathrm{NaHS}$ solution & [35] \\
\hline $\begin{array}{l}\text { Cathode ray tube } \\
\text { powder leachate }\end{array}$ & $\mathrm{Zn}$ & $2.0-2.5$ & $\sim 8.8$ & $\sim 100$ & $\begin{array}{l}\mathrm{Na}_{2} \mathrm{~S} 10 \% w / v \\
\text { solution }\end{array}$ & [36] \\
\hline $\begin{array}{c}\text { Spent refinery catalyst } \\
\text { leachate }\end{array}$ & $\begin{array}{l}\mathrm{Mo} \\
\mathrm{Co} \\
\mathrm{Ni}\end{array}$ & $\begin{array}{l}2.0 \\
3.5 \\
3.5\end{array}$ & Not reported & $\begin{array}{c}36-72 \\
16.0 \\
23.0\end{array}$ & Biogenic $\mathrm{H}_{2} \mathrm{~S}$ & [37] \\
\hline $\begin{array}{l}\text { Lithium ion batteries } \\
\text { (LIBs) leachate }\end{array}$ & Co & $2.9-3.1$ & 2.0 & 99.2 & $\begin{array}{c}\left(\mathrm{NH}_{4}\right)_{2} \mathrm{~S} 10 \% v / v \\
\text { solution }\end{array}$ & [38] \\
\hline $\begin{array}{l}\text { Lithium ion batteries } \\
\text { (LIBs) leachate }\end{array}$ & $\begin{array}{c}\mathrm{Cu} \\
\mathrm{Al} \\
\mathrm{Co} \\
\mathrm{Ni} \\
\mathrm{Zn} \\
\mathrm{Cd} \\
\mathrm{Mn} \\
\mathrm{Fe}\end{array}$ & $\begin{array}{c}3.5-5.0 \\
3.5-5.0 \\
10 \\
10 \\
10 \\
10 \\
10 \\
10\end{array}$ & Not reported & $\begin{array}{l}93.0 \\
98.0 \\
99.9 \\
99.9 \\
98.4 \\
98.6 \\
98.9 \\
99.5\end{array}$ & Biogenic $\mathrm{H}_{2} \mathrm{~S}$ & [39] \\
\hline $\begin{array}{l}\text { Acidic wastewater from } \\
\text { smelters }\end{array}$ & As & $4.0-5.0$ & 3.0 & $97.2-99.1$ & $\begin{array}{l}\mathrm{Na}_{2} \mathrm{~S} 110 \mathrm{~g} / \mathrm{L} \\
\text { solution }\end{array}$ & [40] \\
\hline $\begin{array}{c}\text { Cu smelting ashes } \\
\text { leachate }\end{array}$ & $\begin{array}{l}\mathrm{Pb} \\
\mathrm{Zn}\end{array}$ & $>12.0$ & $2.0-2.5$ & $\begin{array}{l}>99 \\
>99\end{array}$ & $\mathrm{Na}_{2} \mathrm{~S}$ solution & [41] \\
\hline $\begin{array}{c}\text { Acidic wastewater from } \\
\text { smelter }\end{array}$ & $\begin{array}{l}\mathrm{Re} \\
\mathrm{Cu} \\
\mathrm{As}\end{array}$ & $\sim 0$ & Not reported & $\begin{array}{l}98.4-98.9 \\
94.8-98.4 \\
11.6-15.0\end{array}$ & $\begin{array}{l}\text { Saturated } \mathrm{Na}_{2} \mathrm{~S}_{3} \mathrm{O}_{3} \\
\text { solution }\end{array}$ & [42] \\
\hline $\begin{array}{c}\text { Acidic wastewater from } \\
\text { smelter }\end{array}$ & $\mathrm{Cu}$ & $\sim 0$ & $1.5-3.0$ & $70-96$ & $\begin{array}{l}\text { Synthetic monoclinic } \\
\text { FeS }\end{array}$ & [43] \\
\hline $\begin{array}{c}\text { Acidic wastewater from } \\
\text { smelter }\end{array}$ & $\operatorname{Re}$ & $\sim 0$ & Not reported & 99.0 & $\begin{array}{l}\mathrm{H}_{2} \mathrm{~S} \text { with UV } \\
\text { irradiation }\end{array}$ & [44] \\
\hline $\begin{array}{l}\text { PLS from ore } \\
\text { bioleaching }\end{array}$ & $\begin{array}{l}\mathrm{Cu} \\
\mathrm{Zn} \\
\mathrm{Ni} \\
\mathrm{Co}\end{array}$ & $\begin{array}{l}3.2 \\
1.5 \\
2.0 \\
2.0\end{array}$ & Not reported & $\begin{array}{c}>99.9 \\
\text { Not reported } \\
>99.9 \\
>99.9\end{array}$ & Biogenic $\mathrm{H}_{2} \mathrm{~S}$ & [45] \\
\hline $\begin{array}{l}\text { PLS from tailing acid } \\
\text { leaching }\end{array}$ & $\begin{array}{l}\mathrm{Cu} \\
\mathrm{Zn} \\
\mathrm{Cu}\end{array}$ & $\begin{array}{l}3.0 \\
3.6\end{array}$ & $\begin{array}{l}1.2 \\
1.1\end{array}$ & $\begin{array}{l}93.7 \\
89.7 \\
>99\end{array}$ & $\begin{array}{l}\mathrm{Na}_{2} \mathrm{~S} \text { wt. } 0.5 \% \\
\text { solution }\end{array}$ & [46] \\
\hline $\begin{array}{l}\text { PLS from tailing } \\
\text { bioleaching }\end{array}$ & $\begin{array}{l}\mathrm{Pb} \\
\mathrm{Zn} \\
\mathrm{Fe}\end{array}$ & 1.24 & $\begin{array}{l}1.1 \\
2.5\end{array}$ & $\begin{array}{l}>99 \\
>99 \\
75\end{array}$ & $\mathrm{Na}_{2} \mathrm{~S}$ solution & [47] \\
\hline Chloride PLS & $\begin{array}{l}\mathrm{Cu} \\
\mathrm{Zn}\end{array}$ & $\begin{array}{l}1.0 \\
4.0\end{array}$ & Not reported & $\begin{array}{l}99.9 \\
99.9\end{array}$ & $\mathrm{Na}_{2} \mathrm{~S}$ solution & [48] \\
\hline Cyanide PLS & $\mathrm{Cu}$ & $\begin{array}{l}3.5-5.0 \\
3.5-5.5\end{array}$ & $\begin{array}{l}0.4-0.6 \\
1.0-1.2\end{array}$ & $\begin{array}{c}81-99.9 \\
96.4-99.9\end{array}$ & NaHS solution & {$[49,50]$} \\
\hline $\begin{array}{c}\text { Cyanide PLS } \\
\text { Alkaline } \\
\text { glycine-cyanide PLS }\end{array}$ & $\mathrm{Cu}$ & $\begin{array}{c}3.5-5.0 \\
10.0\end{array}$ & $\begin{array}{l}0.5-0.6 \\
1.0-1.6\end{array}$ & $\begin{array}{l}77.5-99.9 \\
71.2-96.5\end{array}$ & $\begin{array}{l}\text { NaHS solution } \\
\text { NaHS solution after } \\
\text { pre-oxidation }\end{array}$ & $\begin{array}{l}{[51-54]} \\
{[55,56]}\end{array}$ \\
\hline
\end{tabular}




\subsection{Acid Mine Drainages (AMD)}

AMD is one of the most harmful and challenging wastewater or liquid waste generated from mining activities. This aqueous drainage can be produced from mine facilities exposed to environment, such as tailings dams, waste rock dumps, or the mine pit [57-59]. AMD can contain high concentrations of metals, metalloids, and sulfate, depending on the ore mineralogy. In this regard, the metal sulfide precipitation has been studied to recover or remove metals from AMD.

The application of metal sulfide precipitation has been widely studied. For example, $\mathrm{H}_{2} \mathrm{~S}$ has been used as a reagent, which is generated through a sulfidogenic process, so that the sulfate contained in the AMD is reduced (biogenic sulfide precipitation, BSP). Recent review articles show advances in BSP for different metals [60], or they are alternatively based on arsenic [61]. These studies have described the bioreactors used to generate $\mathrm{H}_{2} \mathrm{~S}$, the configuration options in the process to optimize the sulfate and metals/arsenic removal, and future applications. Conversely, this work focuses on the metal sulfide precipitation process itself and its downstream operations.

BSP has been used to selectively precipitate copper and zinc in a selective sequential precipitation (SSP) process [9], reaching metal conversions closer to 100\%. BSP has also been used to remove arsenic from AMD. In this regard, Altun and colleagues [5] studied the removal of As from an acidic influent solution, finding an As removal as low as $8 \%$ when the reduction of sulfate was at a maximum, but increasing up to $95.4 \%$ after Fe addition and the reduction of sulfide generation. The addition of iron promotes the As adsorption onto $\mathrm{FeS}$ or the generation of arsenopyrite (FeAsS). Furthermore, the high content of sulfide can re-dissolve the amorphous orpiment $\left(\mathrm{As}_{2} \mathrm{~S}_{3}\right)$ precipitated, according to the following reaction [5]:

$$
3 / 2 \mathrm{As}_{2} \mathrm{~S}_{3}+3 / 2 \mathrm{H}_{2} \mathrm{~S} \rightleftarrows \mathrm{H}_{2} \mathrm{As}_{3} \mathrm{~S}_{6}^{-}+\mathrm{H}^{+}, \mathrm{pK}=5.0
$$

The control of sulfide content could be critical in the final As removal efficiency. Arsenic removal from AMD was also assessed using FeS as a sulfide source [6], finding an inhibition of As removal due to the generation of elemental sulfur by the oxidation of sulfide with $\mathrm{As}(\mathrm{V})$.

The removal of $\mathrm{Sb}$ was studied using a BSP process, reaching higher efficiencies (closer to $100 \%$ ) at $\mathrm{pH} 7.0$, but resulting in a high sulfide/metal ratio equal to 15 [7]. The sulfide precipitate formed was $\mathrm{Sb}_{2} \mathrm{~S}_{3}$. In this case, sulfide must reduce $\mathrm{Sb}(\mathrm{V})$ to $\mathrm{Sb}$ (III) before the final precipitation, increasing the sulfide consumption.

Likewise, a recent study showed the production of metal sulfide nanopowder from AMD using a continuous fluidized bed sulfidogenic bioreactor with two steps at different $\mathrm{pH}$ values (7.0 and 3.0) [13]. The metal conversion was higher than $95 \%$ for $\mathrm{Cu}, \mathrm{Cd}, \mathrm{Pb}$, and $\mathrm{Zn}$ at $\mathrm{pH} 7.0$, and higher than $90 \%$ in the second reactor operating at the lower $\mathrm{pH}$. On the other hand, the removal of $\mathrm{Fe}$ and $\mathrm{Ni}$ was lower than $90 \%$ and higher than $80 \%$ in both reactors, respectively. In addition, copper nanoparticle production with a particle size of $\sim 50 \mathrm{~nm}$ was achieved using the BSP process treating an AMD synthetic solution [15]. The possibility to generate products with high values directly from waste sources should increase in further research of metal sulfide precipitation. This issue is further discussed in Section 7.6, considering different factors that are analyzed in the following sections.

Metal sulfide precipitation was applied in a mine pit by an in situ generation of $\mathrm{H}_{2} \mathrm{~S}$ with a sulfidogenic process, removing copper and arsenic contained in the AMD [62]. This research attempted on site conditions (oxidative and reductive) to assess the sulfidogenic process and metal removal evolution.

Table 2 shows that the application of metal sulfide precipitation in the treatment of AMD is mainly conducted by the use of the BSP process. For all these cases, the main objectives have been addressed to optimize the sulfidogenic bioreaction stage. Hence, the sulfide dosage in terms of molar addition has not been reported, probably due to the excess $\mathrm{H}_{2} \mathrm{~S}$ generated with respect to metals contained in the AMD.

On another note, the application of a chemical source of sulfide has been used to study the selective recovery of metals [10] and the understanding [16] or optimization of solid- 
liquid separation of precipitates [20]. Selective precipitation of copper and zinc, after a rare earth elements (REEs) recovery stage, was proposed by Zhang and Honaker [10] using a $1 \mathrm{M} \mathrm{Na}_{2} \mathrm{~S}$ solution at different $\mathrm{pH}$ values. They achieved metal recoveries above $95 \%$ with metal grades around $40 \%$ in each precipitate, demonstrating the selective separation. $\mathrm{Mn}, \mathrm{Mg}, \mathrm{Ni}$, and $\mathrm{Co}$ were the main impurities detected, with their contents reported below $1.5 \%$.

The precipitation efficiency of metals using a sulfide source from AMD reaches values higher than $90 \%$ in most cases. Moreover, the principal metals studied were $\mathrm{Cu}, \mathrm{Zn}$, and $\mathrm{Fe}$, which are the ones most typically found in AMD.

\subsection{Industrial Wastewater}

Studies reporting the application of the metal sulfide precipitation process in effluents with no specific identification, or that were focused on fundamental advances, were classified as industrial wastewater.

The BSP process has been applied to industrial wastewater to remove or recover $\mathrm{Cu}$, $\mathrm{Zn}$, and Ni $[23,25]$. Furthermore, this method was used to recover Pd and Fe from stripping and scrubbing solutions, respectively, that were generated from a solvent extraction stage [27]. This study was novel in the application of metal sulfide precipitation to recover $\mathrm{Pd}$ as nanosized PdS.

Alternatively, a novel application of metal sulfide precipitation was proposed for thallium removal from industrial wastewater [21]. In this study, the metal sulfide precipitation stage was included to achieve a Tl concentration $<1.0 \mu \mathrm{g} / \mathrm{L}$ in the final effluent after Fenton oxidation (i.e., the use of ferrous ion and hydrogen peroxide to promote co-precipitation with ferric ions) and coagulation stages. This process was also able to remove $\mathrm{Cd}, \mathrm{Pb}$, $\mathrm{Cu}$, and $\mathrm{Zn}$ until reaching trace amounts. Moreover, the $\mathrm{pK}_{\mathrm{sp}}$ of $\mathrm{Tl}_{2} \mathrm{~S}$ reported by the same study was 24.0 , similar to $\mathrm{ZnS}$. The reaction mechanism proposed for the Tl sulfide precipitation was the following [21]:

$$
\begin{gathered}
2 \mathrm{Tl}^{+}+\mathrm{S}^{2-} \rightleftarrows \mathrm{Tl}_{2} \mathrm{~S} \\
2 \mathrm{Tl}^{3+}+3 \mathrm{~S}^{2-} \rightleftarrows \mathrm{Tl}_{2} \mathrm{~S}+2 \mathrm{~S}
\end{gathered}
$$

In addition, metal recovery/removal from plating industrial wastewater has been conducted by using metal sulfide precipitation to treat solutions containing $\mathrm{Cu}, \mathrm{Zn}$, and $\mathrm{Cr}$ [28], and $\mathrm{Cu}, \mathrm{Zn}, \mathrm{Ni}$, and $\mathrm{Fe}$ [29].

\subsection{Leachates from Catalysts, Electronic Waste, and Battery Waste}

The use of metal sulfide precipitation to treat leachates or solutions generated in processes to recycle batteries, electronic waste (Waste Electrical and Electronic Equipment, WEEE), or catalyst wastes has recently increased. This situation is triggered by the need for novel methods to recover valuable metals from emerging wastes, particularly considering the aims of circular economy.

In this vein, the selective recovery of Co and Mo from Co-Mo catalyst leachate was studied using metal sulfide precipitation [32]. Optimum conditions were obtained through the precipitation of Mo from the alkaline leachate generated in the leaching stage. Next, the remaining solution was acidified at $\mathrm{pH} 1.0$ to precipitate Co efficiently. This process reached precipitation efficiencies higher than $98 \%$ for both metals, obtaining products with high purity. In a previous study, Vemic and colleagues [33] evaluated the efficiency of metal sulfide precipitation to recover $\mathrm{Mo}, \mathrm{Co}$, and $\mathrm{Ni}$ from a recycled mineral sludge, reaching optimal efficiencies ( $>95 \%$ ) for synthetic solutions, although these values decreased dramatically to values below $60 \%$ for similar conditions of real solutions. The recovery decline was attributed to the $\mathrm{pH}$ control and the additional sulfide consumption of $\mathrm{Zn}$.

The leaching and recovery of copper from waste printed circuit boards (WPCBs) was conducted using sulfide precipitation on an alkaline glycine leachate [35], obtaining CuS 
with a recovery over $99 \%$ for a sulfide molar ratio of 1.2. Co-precipitation of lead, tin, and zinc was also observed.

More significantly, the metal sulfide precipitation method has recently been applied to recover metals from lithium-ion battery (LIB) leachates [63]. The selective Co recovery from LIB leachate was recently studied by Choubey and colleagues [38], who reported a Co recovery higher than $99 \%$ at a $\mathrm{pH}$ around 3.0, using ammonium sulfide as the precipitant. Previously, Calvert and colleagues [39] studied the recovery of different metals from LIB leachate using a BSP process, reporting high metal recoveries for $\mathrm{Cu}, \mathrm{Al}, \mathrm{Co}, \mathrm{Ni}, \mathrm{Cd}, \mathrm{Zn}$, $\mathrm{Mn}$, and Fe. However, the selective precipitation was only achieved for $\mathrm{Cu}$ and $\mathrm{Al}$ at a lower $\mathrm{pH}(<5.0)$. Other metals formed a bulk precipitate at $\mathrm{pH} 10$. In this case, the performance of a selective precipitation was complicated due to the complexity of the feed solution, given the number of different metals involved in the process.

\subsection{Smelting Leachates and Effluents}

Metal smelters can generate effluents from their gas scrubbing stages [40]. Likewise, some smelters treat their dust by leaching to recover valuable metals [41]. For both cases, the metal sulfide precipitation method has been proposed to remove or recover different elements.

Arsenic removal associated with hydrothermal mineralization stabilization was assessed to reach a stable arsenic sulfide precipitate as the residue [40]. The sulfide precipitation stage could remove $\sim 97 \%$ of As, using sodium sulfate for the mineralization stabilization and reaching $3.9 \mathrm{mg} / \mathrm{L}$ of As after the acid leaching of the residue. These results were considered successful in terms of removal efficiency and residue stabilization.

The recovery of Re from the acidic wastewater of smelters has recently been studied $[42,44]$. In these studies, the precipitation of Re was higher than 98-99\%. In the first study [42], sodium thiosulfate $\left(\mathrm{Na}_{2} \mathrm{~S}_{3} \mathrm{O}_{3}\right)$ was used as a sulfide source in the presence of $\mathrm{SO}_{2}$ and $\mathrm{SO}_{3}$ contained in the acidic stream. Further, a selective precipitation of copper was reached when the oxidation-reduction potential was controlled at $190 \mathrm{mV}$. In the second study [44], the use of UV irradiation was assessed to increase the precipitation rate of $\mathrm{Re}$, obtaining a high conversion rate of $\operatorname{Re}_{2} S_{7}$ and a reduction in the reaction time from $6 \mathrm{~h}$ to $35 \mathrm{~min}$ when UV irradiation was used.

The selective precipitation of copper with synthetic monoclinic pyrrhotite was studied [43], achieving high copper conversions (96\%) with a small co-precipitation of As $(<3 \%)$ for a sulfide dosage molar ratio of 3.0.

\subsection{Leachates Solutions from Ores and Tailings}

An interesting application of the metal sulfide precipitation method is its use in the downstream stage of leaching processes to recover metals from pregnant leach solutions (PLS) or barren leach solutions (BLS) in hydrometallurgical circuits. For both cases, a sequential stage of metal precipitation of $\mathrm{Cu}, \mathrm{Zn}$, and $\mathrm{Ni} / \mathrm{Co}$ was studied using a BSP process [45] from a bioleaching PLS, achieving metal recoveries close to $100 \%$. This process showed the feasibility to selectively recover valuable metals from a polymetallic ore through the rigorous control of the precipitation $\mathrm{pH}$. Similarly, the recovery of $\mathrm{Cu}$ and $\mathrm{Zn}$ was conducted from a PLS generated using a tailing leach, obtaining conversions around 90\% for both metals [46]. Ye and colleagues [47] also applied the metal sulfide precipitation method in a PLS that was a product of the bioleaching of a lead-zinc tailing, recovering $\mathrm{Cu}$, $\mathrm{Pb}, \mathrm{Zn}$, and Fe as a mixed precipitate.

Further, the metal sulfide precipitation has been applied in cyanide solutions to recover cyanide and metals complexed with cyanide. In this system, the simultaneous acidification and sulfide addition promotes the dissociation of cyanide and weak acid dissociable (WAD) metals, such as copper and zinc, forming a sulfide metal precipitate and HCN, which can then be recovered as a source of free cyanide (Equation (8)):

$$
\mathrm{Me}(\mathrm{CN})_{\mathrm{x}}^{\mathrm{y}-\mathrm{x}}+\mathrm{S}^{2-}+\mathrm{xH}^{+} \rightleftarrows \mathrm{MeS}+\mathrm{xHCN}
$$


where Me is a metal. This reaction can be applied at industrial scale in gold cyanidation mining to remove copper and recover cyanide that could be recycled to the cyanide leaching of gold $[3,64]$. The whole process has been called SART (Sulfidization, Acidification, Recycling, and Thickening). The SART process has also been proposed to recover zinc from cyanide solutions [65] and for treating cyanide PLS from gold-copper tailings [66]. Our research group has published different studies related to the application of Equation (8) in cyanide solutions for recovering copper and zinc [49,50] or just copper [51-54]. The successful application of the SART process at an industrial scale is an excellent referent for the scaling-up of the metal sulfide precipitation process for other matrices or applications.

Recent studies of applications of metal sulfide precipitation in an alkaline glycinecyanide solution for recovering copper have shown conversions above $90 \%$ for a sulfide $/ \mathrm{Cu}$ molar ratio of $1.3[55,56]$. These $\mathrm{Cu}$ recovery values were achieved after a pre-oxidation stage, where $\mathrm{Cu}^{+}$was oxidized to $\mathrm{Cu}^{2+}$. When sulfide precipitation was conducted without pre-oxidation, copper recoveries were lower than $70 \%$ [55] because the cuprous ion is associated with cyanide, forming a very stable complex at $\mathrm{pH} 10.5$.

\section{Features of Chemical Reactions and Reactor Design}

\subsection{Reaction Time}

Studies focused on the reaction time and reactor design have recently been published. Table 3 summarizes the main results reported to date in terms of reaction time for different metals/metalloids.

Table 3. Summary of operational conditions and results of maximum conversion and reaction time.

\begin{tabular}{|c|c|c|c|c|c|c|c|}
\hline Element & $\begin{array}{c}\text { Initial } \\
\text { Concentration, } \\
\mathrm{mg} / \mathrm{L}\end{array}$ & $\mathrm{pH}$ & $\begin{array}{l}\text { Sulfide Dosage, } \\
\text { Molar Ratio } \\
\text { (S'-/M) }\end{array}$ & Temperature, ${ }^{\circ} \mathrm{C}$ & $\begin{array}{c}\text { Maximum } \\
\text { Conversion, } \%\end{array}$ & $\begin{array}{l}\text { Reaction Time to } \\
\text { Reach Maximum } \\
\text { Conversion, min }\end{array}$ & Reference \\
\hline $\mathrm{Cu}$ & $500-1800$ & $3.5-5.0$ & $0.5-0.6$ & 15 & $83-99$ & $<1$ & [52] \\
\hline $\mathrm{Cu}$ & 300 & 10.0 & 1.4 & 25 & 96.5 & 5 & [55] \\
\hline $\operatorname{Re}$ & 30 & $\sim 0$ & Not reported & 25 & $97.0^{1}$ & 360 & [44] \\
\hline $\mathrm{Zn}$ & 2350 & \multirow{3}{*}{$>12.0$} & \multirow{3}{*}{2.0} & \multirow{3}{*}{70} & $\sim 100$ & 75 & \multirow{3}{*}{ [41] } \\
\hline $\mathrm{Pb}$ & 4340 & & & & $\sim 95$ & 60 & \\
\hline $\operatorname{Re}$ & $11.5-22.9$ & & & & 98.4 & 60 & \\
\hline $\mathrm{Cu}$ & $16.2-99.9$ & \multirow[t]{2}{*}{$\sim 0$} & \multirow[t]{2}{*}{ Not reported } & \multirow[t]{2}{*}{70} & 98.4 & 60 & \multirow[t]{2}{*}{ [42] } \\
\hline As & $2170-4381$ & & & & 11.6 & 120 & \\
\hline $\mathrm{Cu}$ & 5420 & \multirow[t]{2}{*}{10.6} & \multirow[t]{2}{*}{$1.0-1.2$} & \multirow[t]{2}{*}{25} & 88-99.5 & 5 & \multirow[t]{2}{*}{ [35] } \\
\hline Mo & 1000 & & & & 95 & & \\
\hline $\mathrm{Co}$ & 1000 & \multirow[t]{2}{*}{1.0} & \multirow[t]{2}{*}{10} & \multirow[t]{2}{*}{$20-25$} & 96 & 75 & \multirow[t]{2}{*}{ [33] } \\
\hline $\mathrm{Ni}$ & 1000 & & & & 97 & & \\
\hline As & 12,562 & 4.0 & 3.0 & 25 & 99.1 & 60 & [40] \\
\hline Co & 11,900 & 3.0 & 2.0 & 30 & 98.2 & 30 & [38] \\
\hline As & $1000-5000$ & $\sim 0$ & 2.5 & Room temperature & 99.5 & 60 & [6] \\
\hline $\mathrm{Cu}$ & 120 & 2.5 & \multirow{2}{*}{ Not reported } & \multirow{2}{*}{ Room temperature } & 99.0 & 2.5 & \multirow{2}{*}{ [67] } \\
\hline $\mathrm{Fe}$ & 124 & 7.4 & & & 99.0 & 5.0 & \\
\hline $\mathrm{As}(\mathrm{V})$ & $800-900$ & 1.8 & $10-20$ & Room temperature & $80-85$ & 120 & [68] \\
\hline $\mathrm{Zn}$ & 12,557 & 5.5 & \multirow{4}{*}{ Not reported } & \multirow{4}{*}{$45-85$} & $40-99.7$ & 45 & \multirow{4}{*}{ [69] } \\
\hline $\mathrm{Cd}$ & 6294 & 4.5 & & & $35-97$ & 45 & \\
\hline $\mathrm{Ni}$ & 1232 & 7.5 & & & $35-98$ & 45 & \\
\hline $\mathrm{Cu}$ & 635 & 2.5 & & & $30-97$ & 45 & \\
\hline
\end{tabular}

\footnotetext{
${ }^{1}$ This result corresponds to the base case of this study, without the use of UV light and using $\mathrm{H}_{2} \mathrm{~S}$ gas.
}

According to Table 3, the reaction time to reach a maximum conversion is lower than $120 \mathrm{~min}$ for all cases, except for Re recovery [44], which achieved $97 \%$ after $360 \mathrm{~min}$. This additional time could be a consequence of the use of $\mathrm{H}_{2} \mathrm{~S}$ gas as a sulfide source, which could incorporate an additional stage in the process related to the absorption of $\mathrm{H}_{2} \mathrm{~S}$ gas in the liquid phase that might be able to control the process [70]. However, a previous study also used a $\mathrm{H}_{2} \mathrm{~S}$ gas biologically generated to precipitate $\mathrm{Re}, \mathrm{Cu}$, and As [42], where the maximum conversion for Re was obtained at $60 \mathrm{~min}$. In this case, the effect of temperature could explain a faster reaction.

Even though the results reported in Table 3 were conducted for different metals/metalloids under different conditions of $\mathrm{pH}$, sulfide dosage, and temperature, 
and even when the solution characteristics were different, there are some remarkable patterns. In the case of $\mathrm{Cu}$, the reaction times are significantly lower $(<5 \mathrm{~min})[35,52,55,67]$, except in two cases. The first one reached the maximum conversion at $60 \mathrm{~min}$ [42] by using gaseous $\mathrm{H}_{2} \mathrm{~S}$, which adds an absorption process as an additional stage. This fact could limit the reaction time. In the second case, the sulfide source used was thioacetamide [69], which requires a dissociation reaction to release $\mathrm{H}_{2} \mathrm{~S}$. On the other hand, studies reporting fast reactions for $\mathrm{Cu}$ used a conventional sulfide source dissolved in liquid phase. Further, the reaction time for a maximum As removal ranged from 60 to $120 \mathrm{~min}[6,40,42,68]$.

Unfortunately, there is a lack of research focusing on kinetic aspects, in terms of estimating kinetic constants and Arrhenius parameters. This gap of knowledge limits the extrapolation and scaling-up of lab-scale results to different operational conditions. Yang and colleagues [71] reported the only study where a kinetic model for copper precipitation was proposed, according to the following equation:

$$
\mathrm{r}_{\mathrm{Cu}^{2+}}=\mathrm{r}_{\mathrm{S}^{2-}}=-\mathrm{k}\left[\mathrm{Cu}^{2+}\right]\left[\mathrm{S}^{2-}\right]
$$

where $\mathrm{r}_{\mathrm{Cu} 2+}$ and $\mathrm{r}_{\mathrm{S} 2-}$ represents the reaction rates of copper $\left(\mathrm{Cu}^{2+}\right)$ and sulfide $\left(\mathrm{S}^{2-}\right)$, respectively, $\mathrm{k}$ is the reaction rate constant, $\left[\mathrm{Cu}^{2+}\right]$ is the copper concentration, and $\left[\mathrm{S}^{2-}\right]$ is the sulfide concentration. The $\mathrm{k}$ value obtained was $9.989 \mathrm{~mol} \mathrm{~s}^{-1} \mathrm{~m}^{-3}$ [71] with a regression of $\mathrm{R}^{2}=0.9957$. These results confirm the validity of the kinetic model proposed in Equation (9), although this assessment was performed for one concentration of copper and sulfide, respectively. Therefore, this result indicates the need to study kinetic models further.

An interesting phenomenon has been reported by some studies regarding the redissolution of metal sulfide precipitates after longer reaction times. Vemic and colleagues [33] reported a decrease in metal conversion after achieving the maximum conversion at 75 min (see Table 3), reaching a final conversion of $80 \%$ at $125 \mathrm{~min}$. They explained the potential oxidation and dissolution as an effect of the dissolved oxygen. Similarly, Deng and colleagues [55] found a gradual and slow decrease in copper conversion after reaching the maximum conversion of $96.5 \%$ at 5 min (see Table 2), reaching a final conversion of $89.8 \%$ at $60 \mathrm{~min}$. These results are consistent with a previous study about the application of the SART process for recovering cyanide and copper from gold tailings [72]. In this study, copper conversion also decreased for longer reaction times. Different chemical reactions of the oxygen oxidation effect, promoting the dissolution of copper precipitates, were proposed for this system according to the following equations:

$$
\begin{gathered}
\mathrm{Cu}_{2} \mathrm{~S}_{(\mathrm{s})}+1 / 4 \mathrm{O}_{2}+2 \mathrm{HCN} \rightleftarrows \mathrm{CuS}_{(\mathrm{s})}+\mathrm{Cu}(\mathrm{CN})_{2}^{-}+\mathrm{H}^{+}+1 / 2 \mathrm{H}_{2} \mathrm{O} \\
\mathrm{Cu}_{2} \mathrm{~S}_{(\mathrm{s})}+1 / 2 \mathrm{O}_{2}+2 \mathrm{H}_{2} \mathrm{~S} \rightleftarrows 2 \mathrm{CuS}_{(\mathrm{s})}+\mathrm{H}_{2} \mathrm{O} \\
\mathrm{CuS}_{(\mathrm{s})}+1 / 4 \mathrm{O}_{2}+5 \mathrm{HCN} \rightleftarrows 2 \mathrm{Cu}(\mathrm{CN})_{2}^{-}+2 \mathrm{SCN}^{-}+4 \mathrm{H}^{+}+1 / 2 \mathrm{H}_{2} \mathrm{O}
\end{gathered}
$$

These incipient results demonstrate that the definition of the reaction time for designing purposes should be studied for each chemical system. In addition, further studies about the impact of oxygen oxidation on different metals/metalloids should be performed.

\subsection{Reactor Type}

The most conventional reactor type used at the laboratory scale, and even at the industrial scale, for metal sulfide precipitation is the continuous stirred-tank reactor (CSTR). At a laboratory scale, the simplicity of the CSTR, and the easy comparison with results from other studies, could explain the preference. Likewise, the use of the CSTR at the industrial scale, such as in the SART process [3] or for treating AMD [4], is preferred over other reactor technologies. Nevertheless, the industrial plants of metal sulfide precipitation use a sulfide source in liquid phase - typically a NaHS solution-minimizing the reaction time because the limiting stage of gas absorption is avoided, as typically found in the BSP 
processes [70]. Even though the CSTR is the most commonly used reactor type, there were studies that assessed different reactor types or configurations. In this regard, a fluidized bed reactor (FBR) (Figure 3) was first used by van Hille and colleagues for supersaturation control studies [73], and afterwards by Mokone and colleagues [74]. The latter concluded that the fluidized bed reactor is not suitable for metal sulfide precipitation application due to the difficulty for controlling the supersaturation. In the next section, the supersaturation in metal sulfide precipitation will be discussed.

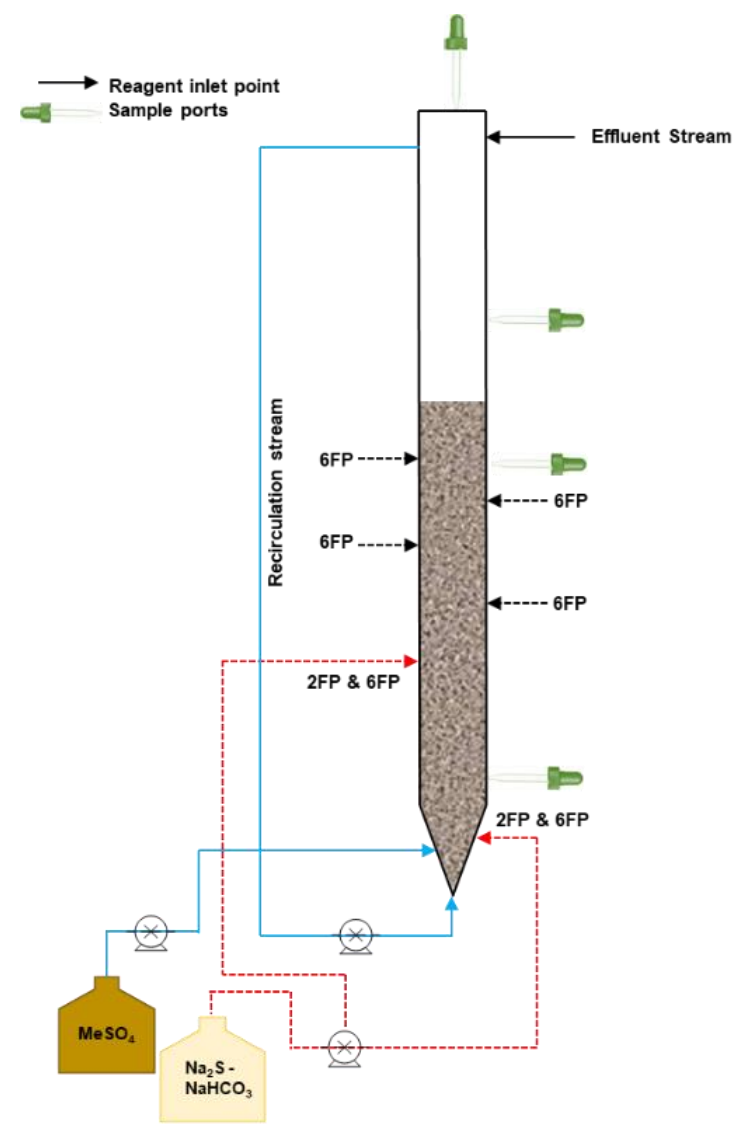

Figure 3. Fluidized bed reactor prototype used by Mokone and colleagues [74] to assess the supersaturation control in metal sulfide precipitation. FP represents the sulfide feed points defined in the study. Adapted from [74].

For BSP processes, different types of bioreactors have been proposed and studied [60]. When using this method, a single-stage (i.e., sulfate reduction and sulfide precipitation occur in the same reactor) and two- or multiple-stage (i.e., sulfate reduction and sulfide precipitation are performed in different reactors) reactors were evaluated. For singlestage reactors, the inverse fluidized bed reactor (IFBR) [75] and the FBR [76] were tested. However, for two- or multi-stage operations, the metal sulfide precipitation reactor was applied in conventional CSTR [60]. The main drawbacks, benefits, and an exhaustive summary of different bioreactors assessed for sulfate reduction can be found in the review article by Kumar and colleagues [60].

In this vein, the operational behavior of three continuous-flow sulfide precipitation reactors (CFSPR) was analyzed through mathematical modeling and experimental studies [71] performing different sulfide dosage configurations, as shown in Figure 4. Reactor $\mathrm{N}^{\circ} 3$ reached a better performance due to the ideal mixing state and suitable retention time. 


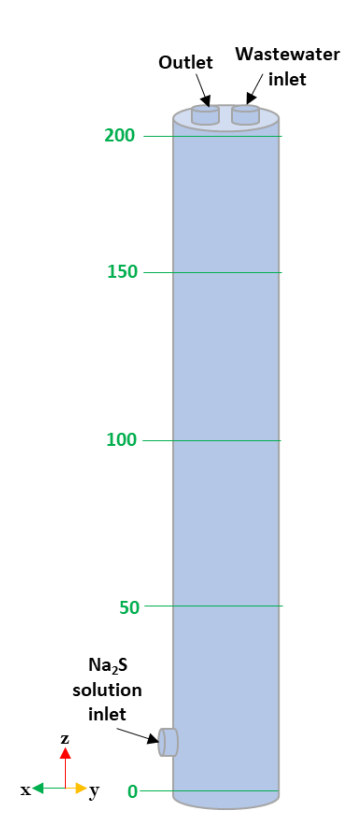

a)

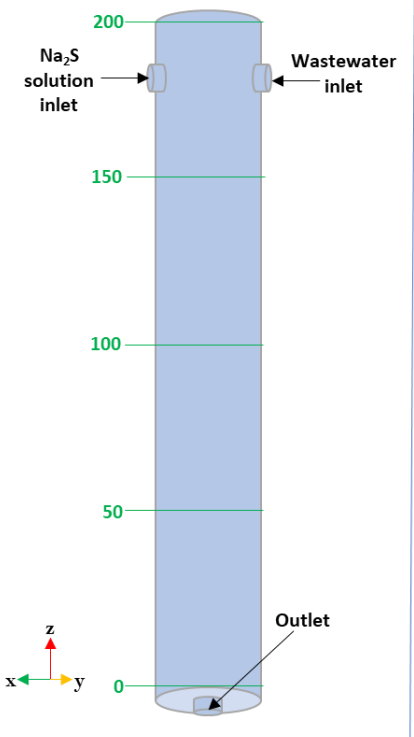

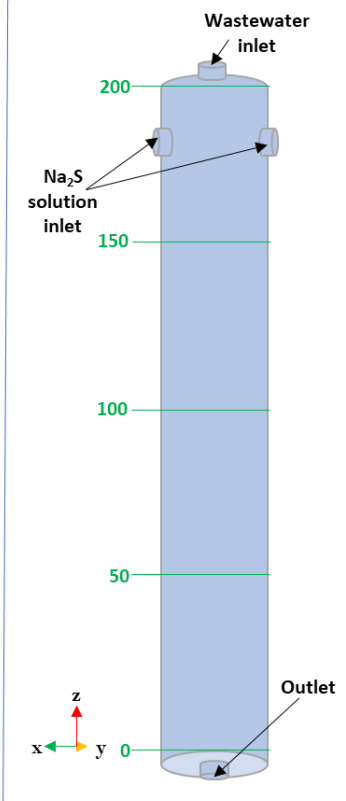

c)

Figure 4. Geometry proposed for three CFSPR assessed by Yang and colleagues [71]. (a) $\mathrm{N}^{\circ} 1,(\mathbf{b}) \mathrm{N}^{\circ} 2$, and (c) $\mathrm{N}^{\circ}$. Adapted from [71].

Guo and colleagues [26] proposed a novel sulfide distributor device to dose sulfide, controlling the supersaturation in the removal of arsenic (see Figure 5). According to this study, the arsenic removal increased from around $80 \%$ to almost $100 \%$ when the distributor was used. This increase was a consequence of improving the mix and elimination of the supersaturation zones of the reactor [26].

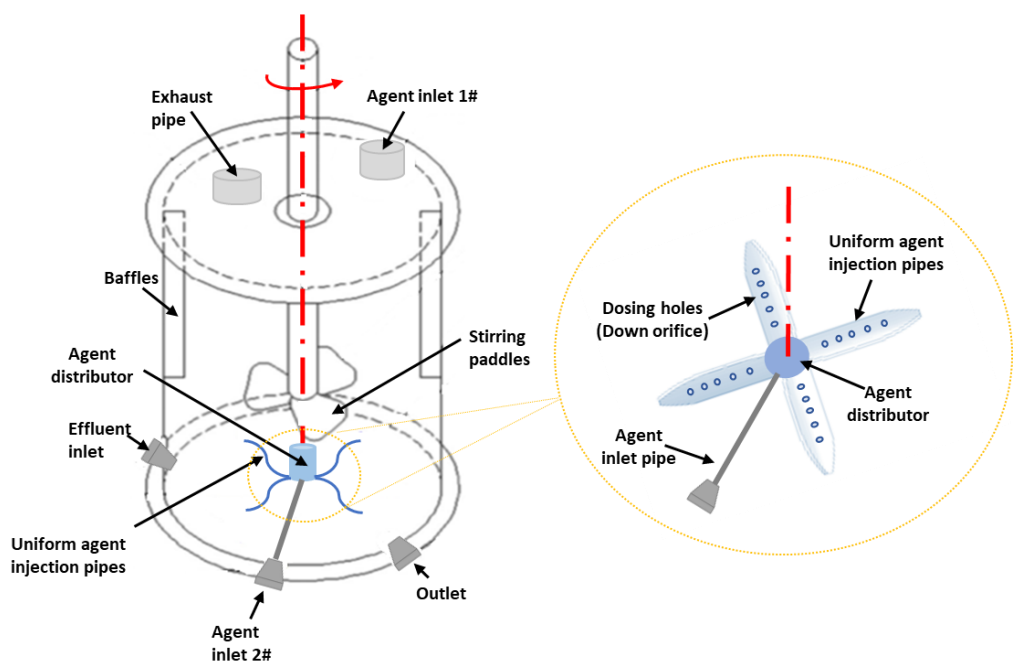

Figure 5. Sulfide distributor device proposed by Guo and colleagues [26] to control the supersaturation. Adapted from [26].

\subsection{Supersaturation Features}

The supersaturation can be estimated according to the following equation [74]:

$$
\mathrm{S}=\left(\frac{\left[\mathrm{Me}^{2+}\right]\left[\mathrm{HS}^{-}\right]}{\mathrm{K}_{\mathrm{sp}}}\right)^{\frac{1}{v}}
$$


where $S$ is the supersaturation, $\left[\mathrm{Me}^{2+}\right]$ is the activity of the metal, $\left[\mathrm{HS}^{-}\right]$is the activity of sulfide, $\mathrm{K}_{\mathrm{sp}}$ is the molal based solubility product of the sulfide metal, and $v$ is the number of ions in a formula unit of the salt. According to the classic precipitation theory, the supersaturation level establishes the particle size distribution of precipitates [73]. This implies that when supersaturation is high, fine and colloidal particles will be formed. In this regard, van Hille and colleagues [73] found that fine particles $(<0.22 \mu \mathrm{m})$ were generated, affecting the copper conversion caused by the loss of copper precipitates through the reactor overflow. Similarly, Mokone and colleagues [74] demonstrated that the supersaturation control by a FBR for copper and zinc precipitates was very difficult, concluding that the FBR is not suitable for this application, as mentioned earlier. This conclusion is supported by the extremely low value of $\mathrm{K}_{\mathrm{sp}}$ for metal sulfide (see Table 1), which results in high supersaturation values, even when low contents of sulfide are added. On the contrary, the methodology proposed by Guo and colleagues [26] could increase the arsenic removal due to the control of supersaturation using the novel sulfide distributor shown in Figure 5. These opposite results could be a consequence of the difference between $\mathrm{K}_{\mathrm{sp}}$ values of $2.1 \times 10^{-22}$ [40] and $1.3 \times 10^{-36}$ [2] for $\mathrm{As}_{2} \mathrm{~S}_{3}$ and CuS, respectively. This difference means that there is a low supersaturation value for As, and that the supersaturation control might be more relevant for this metalloid.

In addition, the control of supersaturation for zinc sulfide precipitation was studied by Sampaio and colleagues [77], who claimed that a large particle size was achieved when supersaturation was lower. These results agree with the particle size distributions determined by Mokone and colleagues [74] for zinc precipitates, which were larger than copper precipitates for a controlled sulfide dosage. Zinc sulfide has a lower solubility $\left(3.0 \times 10^{-25}\right)$ with respect to As, but it is significantly higher than copper sulfide. Therefore, the supersaturation control could be suitable for more soluble metal sulfides; however, further specific studies are required to support these findings.

Additionally, computational fluid dynamics (CFD) modeling was conducted to estimate the supersaturation in a CFSPR for copper sulfide precipitation with $\mathrm{H}_{2} \mathrm{~S}$ gas as a sulfide source [78]. The supersaturation was controlled by the gas flow rate and bubble size. Nonetheless, in this case, there were no measurements of particle size distribution in order to accurately assess the effect of supersaturation control.

\subsection{Effect of Excess Sulfide}

The detrimental effect of excess sulfide has been reported earlier for arsenic removal (Equation (5)) and copper recovery in gold cyanidation (Equations (11)-(12)). In both cases, it promoted the re-dissolution of the precipitate. Likewise, van Hille and colleagues [73] suggested that the excess of sulfide could also promote the generation of soluble polysulfide complexes for copper precipitation, according to the following reactions:

$$
\begin{aligned}
& \mathrm{Cu}^{2+}+3 \mathrm{HS}^{-} \rightleftarrows \mathrm{CuS}(\mathrm{HS})_{2}^{2-}+\mathrm{H}^{+} \\
& \mathrm{Cu}^{2+}+4 \mathrm{HS}^{-} \rightleftarrows \mathrm{CuS}(\mathrm{HS})_{3}^{3-}+\mathrm{H}^{+}
\end{aligned}
$$

These reactions can be favorable for high sulfide concentration and low copper concentration, limiting the possibility to obtain a maximum conversion. The generation of these poly-sulfide complexes could promote the adsorption of other cations present in the solution. Deng and colleagues [55] concluded that gold losses could be related to an effect of the gold adsorption on copper poly-sulfide complexes. Hence, the addition of sulfide must be made carefully, not only to avoid an increase in operational costs, but also to limit the reduction of the precipitation performance and loss of valuable cations.

\section{Sulfide Reagent Sources}

As mentioned in Section 2 and depicted in Table 2, there are several conventional sulfide sources used for metal sulfide precipitation processes. Typically, the use of $\mathrm{Na}_{2} \mathrm{~S}$ and NaHS solutions are implemented at an industrial scale [3,4], and the study of the 
BSP method gains interest in the scientific community due to the possibility of removing sulfate, generating the sulfide source. The description and main findings regarding BSP are detailed in recent review articles [60,79]. Therefore, this section is not focused on conventional sulfide sources or the BSP method, but it describes novel trends in the use of alternative sulfide sources or proposals for new materials or methods to release this reagent.

Thioacetamide $\left(\mathrm{CH}_{3} \mathrm{CSNH}_{2}\right)$ was first proposed to control the sulfide concentration in the solution [69], according to the following reaction:

$$
\mathrm{CH}_{3} \mathrm{CSNH}_{2}+2 \mathrm{H}_{2} \mathrm{O} \rightleftarrows \mathrm{CH}_{3} \mathrm{COOH}+\mathrm{NH}_{3}+\mathrm{H}_{2} \mathrm{~S}
$$

Conversion results obtained from the first study related to this topic [69] were promising, where the reaction time was lower than that found in other studies using conventional sulfide sources (see Table 3). This situation could probably be explained by the additional reaction step of $\mathrm{H}_{2} \mathrm{~S}$ generation. A later study demonstrated metal $(\mathrm{Cu}, \mathrm{Ni}$, and $\mathrm{Zn})$ conversions above $90 \%$, but after 30-60 min of reaction time [80], which confirms the previous results shown by Gharabaghi and colleagues [69].

Residue from other industries was also used as a sulfide source, promoting the development of circular economy. Heavy oil fly ash (HOFA), with more than $9.0 \% w / w$ of sulfur content, was used to remove copper from a synthetic solution [81]. Results showed a copper conversion of $\sim 99 \%$ for the optimal operational conditions found. Accordingly, promising results are expected when using residues with high sulfur contents. However, some features related to the release and control of other pollutants from the residue remain unknown and unassessed until now.

A study using monoclinic pyrrhotite $\left(\mathrm{Fe}_{(1-\mathrm{x})} \mathrm{S}\right.$, a nonstoichiometric variant of $\left.\mathrm{FeS}\right)$ as a sulfide source assessed the impact of different qualities of pyrrhotite on the selective removal of copper from arsenic contained in acidic wastewater of refineries [43]. The use of $\mathrm{FeS}$ is based on the low solubility that $\mathrm{CuS}\left(\mathrm{K}_{\mathrm{sp}}=1.3 \times 10^{-36}\right)$ has with respect to $\mathrm{FeS}$ $\left(\mathrm{K}_{\mathrm{sp}}=1.6 \times 10^{-19}\right)$ and $\mathrm{As}_{2} \mathrm{~S}_{3}\left(\mathrm{~K}_{\mathrm{sp}}=2.1 \times 10^{-22}\right)$. Likewise, the higher solubility of FeS compared with $\mathrm{As}_{2} \mathrm{~S}_{3}$ allows for a controlled release of sulfide, promoting the precipitation of $\mathrm{CuS}$ instead of $\mathrm{As}_{2} \mathrm{~S}_{3}$, according to the following general reactions:

$$
\begin{gathered}
2 \mathrm{FeS}+\mathrm{Cu}^{2+}+\mathrm{H}^{+} \rightleftarrows 2 \mathrm{Fe}^{2+}+\mathrm{HS}^{-}+\mathrm{CuS} \\
\mathrm{Cu}^{2+}+\mathrm{HS}^{-} \rightleftarrows \mathrm{CuS}+\mathrm{H}^{+}
\end{gathered}
$$

Synthetic monoclinic pyrrhotite was more effective in removing copper with respect to natural pyrrhotite. The slow release of sulfide allowed the selective precipitation of copper, reaching precipitates with $20 \%$ of $\mathrm{Cu}$ and $0.7 \%$ As, with copper conversions of $96 \%$ for a dosage with a molar ratio of 3.0 sulfide/copper. The extremely uneven structure of the synthetic pyrrhotite, exhibiting a gully shape with sharp edges, triggers a larger specific surface area for reaction in comparison to the compact structure of natural pyrrhotite [43].

Although the CaS is defined as a conventional source of sulfide, its application at a laboratory and industrial scale has limited public knowledge. The assessment of sulfide precipitation with $\mathrm{CaS}$ in the presence of $\mathrm{CO}_{2}$ demonstrated a high conversion of $\mathrm{Ni}, \mathrm{Co}$, $\mathrm{Zn}(>99 \%)$, and $\mathrm{Fe}(>95 \%)$, controlling the content of $\mathrm{Ca}^{2+}$ due to the formation of $\mathrm{CaCO}_{3}$ with $\mathrm{CO}_{2}$ [82]. The use of $\mathrm{CaS}$ could be an excellent alternative for some applications where it is necessary to avoid the addition of $\mathrm{Na}$, which can increase the solubility of other pollutants, such as sulfate.

Moreover, a disproportionation reaction was studied using different sources of oxidized sulfur. In particular, the use of thiosulfate was tested to precipitate rhenium from an acidic solution containing $\mathrm{SO}_{2}$ and $\mathrm{SO}_{3}$ [42]. This study was included in Tables 2 and 3 . Likewise, the use of elemental sulfur with $\mathrm{SO}_{2}$ was assessed for recovering copper under high acidic conditions with the aim of avoiding the generation of elemental sulfur by the oxidation of the excess sulfide [83]. Copper conversion reached around $100 \%$ after $120 \mathrm{~min}$ 
at $72.7^{\circ} \mathrm{C}$ using a 1.0 sulfide/copper molar ratio. The reaction mechanism proposed by this study is shown in the following equations:

$$
\begin{gathered}
\mathrm{SO}_{2}+\mathrm{H}_{2} \mathrm{O} \rightleftarrows \mathrm{H}_{2} \mathrm{SO}_{3} \rightleftarrows \mathrm{H}^{+}+\mathrm{SO}_{3} \mathrm{H}^{-} \\
\mathrm{S}+\mathrm{SO}_{3} \mathrm{H}^{-}+\mathrm{H}_{2} \mathrm{O} \rightleftarrows \mathrm{S}_{2} \mathrm{O}_{3} \mathrm{H}^{-}+\mathrm{H}_{2} \mathrm{O} \rightleftarrows \mathrm{HS}^{-}+\mathrm{SO}_{4} \mathrm{H}^{-}
\end{gathered}
$$

Even though the main formed species was $\mathrm{CuS}$, the study also found the presence of $\mathrm{Cu}_{2} \mathrm{~S}$. Both copper species were deposited onto the sulfur particle surface, generating a products' layer that can simulate the unreacted or shrinking core model [83].

Sulfide sources have been studied to remove metals through the fabrication of novel materials that contain sulfide. Firstly, sulfide $\left(\mathrm{Na}_{2} \mathrm{~S}\right)$ was intercalated in hydrotalcite material (layered double hydroxide, $\mathrm{LDH}$ ), producing an adsorption material able to remove metals and anionic pollutants [84]. Sulfide content allowed increasing Co and $\mathrm{Ni}$ removal in $405 \%$ and $281 \%$, respectively, with respect to a pristine LDH material with no sulfide contents.

Recently, a calcium sulfide-organosilicon complex (CaS-OSCS) was developed via coordination bonding, coating the $\mathrm{CaS}$ into a matrix of $\left\{\left[\mathrm{O}_{1.5} \mathrm{Si}\left(\mathrm{CH}_{2}\right)_{3} \mathrm{NH}\right] \mathrm{CS}\right\}_{\mathrm{n}}(\mathrm{OSCS})$ with the aim of controlling the sulfide release to reduce the sulfide consumption [85]. This novel material was applied to selectively remove copper and arsenic from an acidic wastewater. The final conversion reached $99 \%$ and $98 \%$ after $50 \mathrm{~min}$ for copper and arsenic, respectively. However, this maximum copper conversion was achieved at $9 \mathrm{~min}$, while arsenic only reached $4 \%$ at this time, demonstrating the feasibility to selectively remove both elements. Lastly, the sulfide reagent consumption was reduced by 30\% compared with CaS [85].

The development of new materials using sulfide in their structure is a promising area to encourage processes focused on metal recovery or removal, in order to control the supersaturation and/or reduce the reagent consumption.

\section{Characteristics of Precipitates}

The main focus of metal sulfide precipitation studies is its application in different feed streams and wastewaters. In addition, it points at understanding the recovery or removal mechanisms of different metals and metalloids, as previously shown. Nevertheless, when the overall process (Figure 2) is analyzed, the solid-liquid separation stage plays a key role to ensure that the conversion achieved in the reaction stage will be similar to the overall process efficiency. The achievement of this goal strongly depends on the performance of the solid-liquid separation equipment. However, a reliable and optimized performance of the solid-liquid separation equipment depends on understanding the particles' behavior contained in the feed suspension. In this regard, the low solubility of sulfide precipitates translates into a high supersaturation, promoting the generation of a large number of small particles, which are typically difficult to separate from the solution [16].

The effect of solution chemistry on particle characteristics [16], the effect of the postprecipitation conditions on colloidal metal sulfide precipitates [86], and the effect of dissolved precipitating ions on the settling characteristics of copper sulfide precipitates [87] were studied based on testing the zeta potential (i.e., potential difference between the solid surface of the precipitate and the bulk of solution) of precipitates under different conditions. These studies focused on the application of metal sulfide precipitation in synthetic AMD.

A large number of small particles of copper sulfide formed when the sulfide metal ratio was higher and when the $\mathrm{pH}$ had increased $(<1 \mu \mathrm{m}$ for both cases). On the other hand, the particle size of zinc sulfide precipitates did not show a significant effect on the sulfide content. A slight size increase effect was observed, nevertheless, when the $\mathrm{pH}$ decreased [16], which resulted in particle sizes between 1 and $20 \mu \mathrm{m}$. For both cases, the aggregation capacity of precipitates increased for $\mathrm{pH}$ values lower than 6.0. These results are in line with the settling tests results, which showed better findings for size distributions having larger particles. Results of zeta potential measurements showed lower values for copper sulfides compared to zinc sulfides, suggesting that the aggregation capacity of 
copper precipitates was lower. This result agreed with the particles size measured, which showed higher values for zinc sulfides. Moreover, the zeta potential tendencies obtained for both precipitates with respect to the sulfide/metal ratio and $\mathrm{pH}$ were consistent with the particle size determined, being that the zeta potential decreased when $\mathrm{pH}$ increased and also decreased for higher sulfide/metal ratios [16].

Later, the effect of $\mathrm{pH}$, sulfide concentration, and the addition of divalent $\left(\mathrm{Ca}^{2+}\right)$ and trivalent $\left(\mathrm{Al}^{3+}\right)$ ions on the surface charge and aggregation capacity were assessed [86]. The zeta potential decreased for copper and zinc sulfides when $\mathrm{pH}$ increased from 6.0 to 11.0, which shows a similar tendency as the previous study [16]. Nonetheless, in this case, the effect of sulfide ions on the zeta potential and the subsequent aggregation capacity was more in line with the findings of the previous work, showing a decrease in the zeta potential for high sulfide concentration. This effect was attributed to the adsorption of sulfide ions on particle surfaces. Further, the addition of divalent ions did not promote aggregation, but the addition of a small amount of trivalent ions increased the surface charge significantly, triggering particle aggregation [86]. Similar tendencies of the zeta potential were found by Nduna and colleagues [87] for copper sulfide precipitates in comparison to $\mathrm{pH}$ and sulfide concentration.

Similar results for zeta potential were obtained for $\mathrm{ZnS}, \mathrm{CuS}$, and PbS. For all cases, values of zeta potential decreased when sulfide dosage increased, thus obtaining a significant decrease in the particle size distribution from $20 \mu \mathrm{m}$ to $0.2 \mu \mathrm{m}$ for $\mathrm{ZnS}$, from 40 $\mu \mathrm{m}$ to $0.1 \mu \mathrm{m}$ for CuS, and from $40 \mu \mathrm{m}$ to $0.3 \mu \mathrm{m}$ for PbS, when the sulfide/metal molar ratio increased from 1.0 to 3.0 [88]. These results are in agreement with the turbidity values obtained for each case, where better results were reached for lower sulfide dosages.

A model to predict the zeta potential with $\mathrm{pH}$ for covellite $(\mathrm{CuS})$ was developed based on the adsorption of protons and crystallographic data [89]. The model adequately reproduced the experimental data.

The characterization of copper and zinc precipitates produced with biogenic sulfide, in terms of morphology, mineralogy, and solid-liquid separation was conducted by VillaGomez and colleagues [90]. X-ray diffraction results agree with those obtained by Mokone and colleagues [86], demonstrating the presence of $\mathrm{Cu}$ as $\mathrm{CuS}$ and $\mathrm{Zn}$ as $\mathrm{ZnS}$. CuS was predominantly amorphous regardless of $\mathrm{pH}$, and $\mathrm{ZnS}$ showed a more organized structure at $\mathrm{pH} 5$ compared to $\mathrm{pH} 3.0$ and 7.0. Particle size distributions showed larger particles for $\mathrm{pH}$ values lower than 5.0, reaching values up to $30-40 \mu \mathrm{m}$, compared to the particle size obtained at $\mathrm{pH} 7.0(<10 \mu \mathrm{m})$. Turbidity results showed a decline for lower sulfide dosages.

A precipitate characterization was performed for copper and zinc sulfides, obtained from a sulfide precipitation in cyanide media [49]. For copper precipitates, $\mathrm{X}$-ray diffraction results showed that around $50-55 \%$ of particles were amorphous, containing $\mathrm{CuS}, \mathrm{Cu}_{2} \mathrm{~S}$, and $\mathrm{Cu}_{7} \mathrm{~S}_{4}$ at $\mathrm{pH} 5.0$, but without $\mathrm{Cu}_{2} \mathrm{~S}$ at $\mathrm{pH} 3.5$, probably because the stability zone of $\mathrm{CuS}$ is wider for lower $\mathrm{pH}$ values. Zeta potential results for $\mathrm{ZnS}$ were similar to those obtained previously in AMD systems, showing a decline with the increase in $\mathrm{pH}$. Nevertheless, the zeta potential for copper sulfide increased with a rise in $\mathrm{pH}$, an opposite result compared with the previous studies described here. Despite this, the zeta potential of copper sulfides immersed in $\mathrm{KCl}$ solution showed similar values regardless of $\mathrm{pH}$.

Figure 6 shows a summary of values of the zeta potential obtained and compared to the zeta potential resulted in a previous study [86]. The magnitudes and tendencies of the zeta potential obtained by Gim-Krumm and colleagues [49] did not agree with the aggregate sizes obtained, which reached values even higher than $500 \mu \mathrm{m}$ for copper sulfide. Instead, zinc sulfides were lower than $50 \mu \mathrm{m}$ (see Figure 7). 


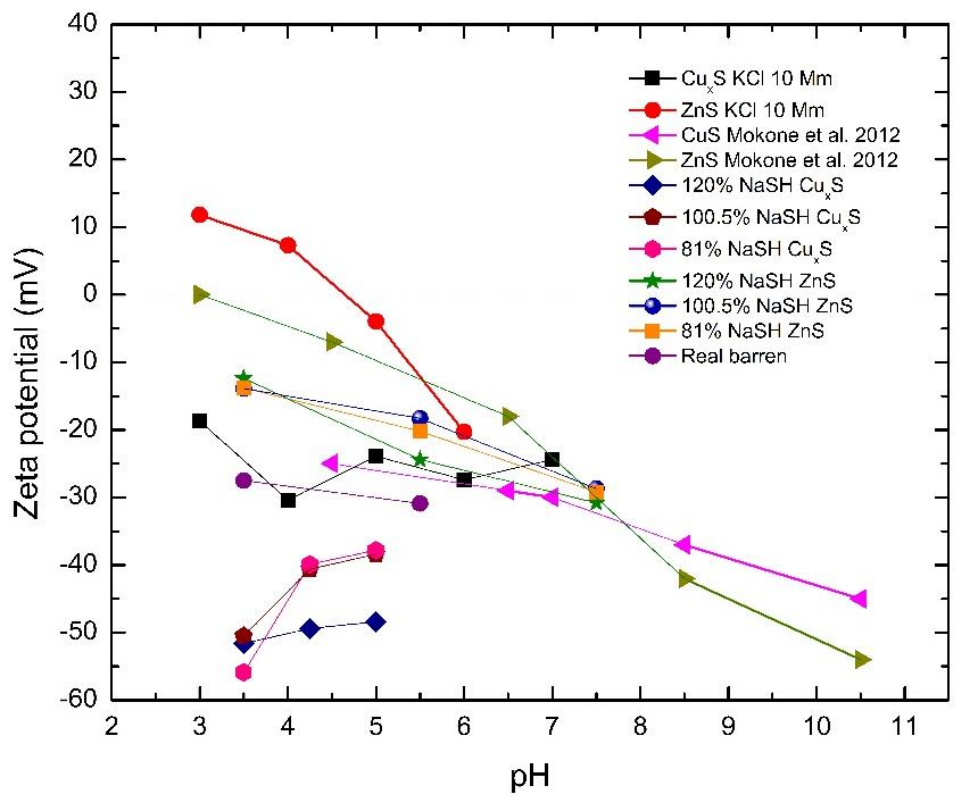

Figure 6. Zeta potential values obtained by Gim-Krumm and coleagues [49] for $\mathrm{Cu}_{\mathrm{x}} \mathrm{S}$ and $\mathrm{ZnS}$, compared to previous results by Mokone and colleagues [86]. Adapted from [49].
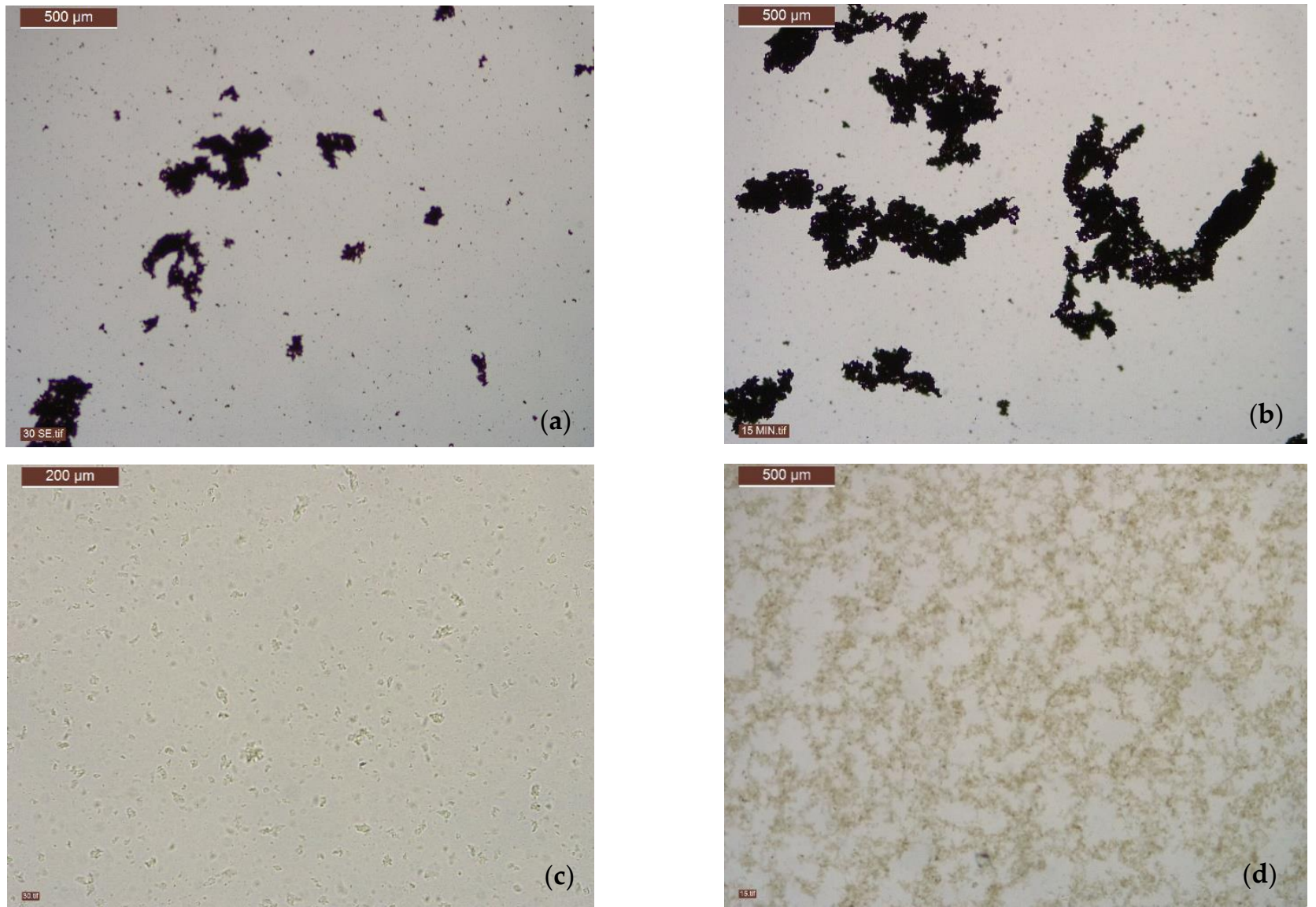

Figure 7. Optical micrographs for sulfide precipitates obtained by Gim-Krumm and colleagues [49] at pH 3.5 with a 1.2 sulfide/metal molar dosage. (a) copper at $30 \mathrm{~s}$; (b) copper at $15 \mathrm{~min}$; (c) zinc at $30 \mathrm{~s}$; (d) zinc at $15 \mathrm{~min}$. 
The study conducted by Gim-Krumm and colleagues [49] was the first one that performed a computational chemistry analysis, demonstrating the relevance of the interaction of metal sulfide precipitates with the solvent. In the case of copper sulfides, its hydrophobicity promotes the aggregation between particles instead of the zinc sulfides, which tends to form bonds with water, and it is thereby more influenced by the chemical changes of the solvent (e.g., $\mathrm{pH}$ or sulfide content). This behavior explained a more colloidal behavior of $\mathrm{ZnS}$ with respect to $\mathrm{Cu}_{\mathrm{x}} \mathrm{S}$. An expanded study of this computational chemistry analysis (density functional analysis, DFT) was published by Wrighton-Araneda and colleagues [91]. Recently, Xia and colleagues [92] experimentally confirmed it: using computational chemistry analysis (DFT), they proved that the hydrophobicity/hydrophilicity capacity is essential to obtain the aggregation capacity of metal sulfide precipitates. In that study, the analysis focused on CuS, CdS, $\mathrm{As}_{2} \mathrm{~S}_{3}$ (Figure 8), and ZnS. Herein, they concluded that hydrophilic sulfide precipitates were difficult to be separated through the settling and coagulation method, confirming the previous findings reported by Gim-Krumm and colleagues [49].
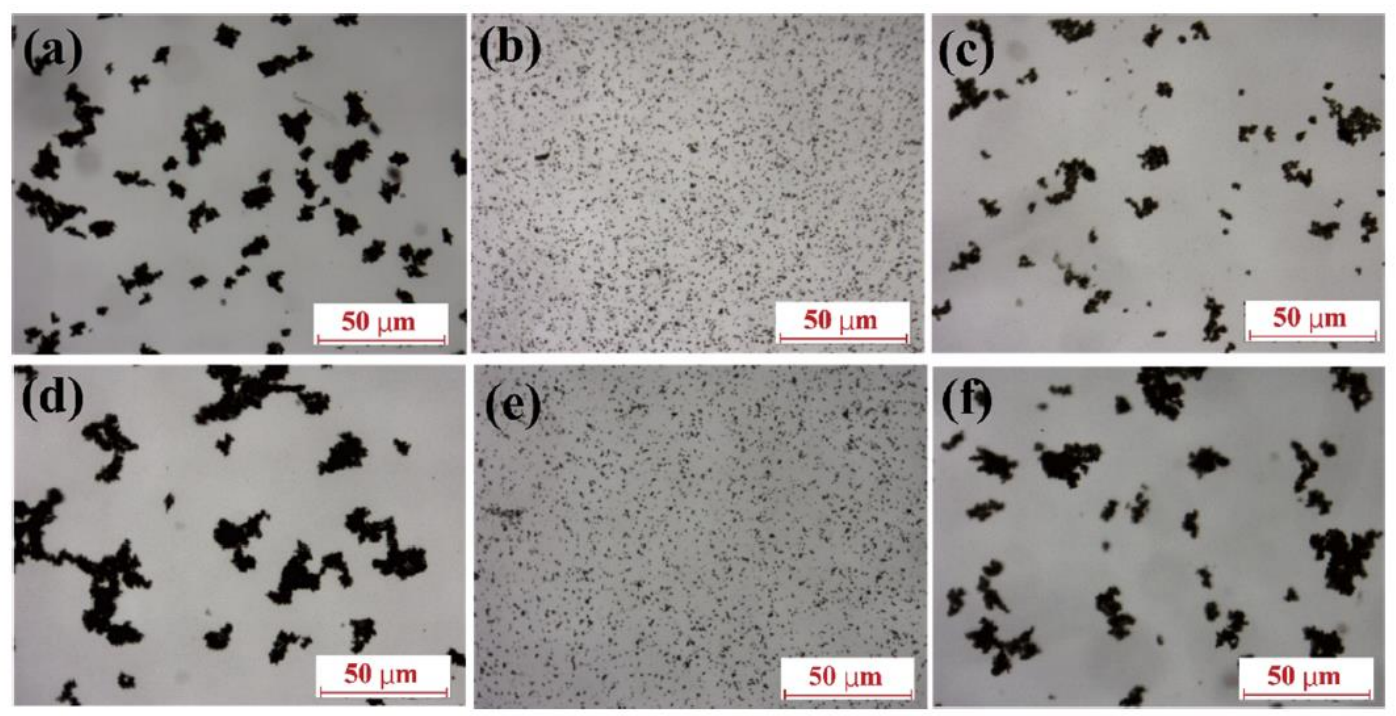

Figure 8. Optical micrographs for sulfide precipitates obtained by Xia and colleagues [92] with $\mathrm{H}_{2} \mathrm{~S}$ in strongly acidic wastewater. (a) CuS; (b) CdS; (c) $\mathrm{As}_{2} \mathrm{~S}_{3}$ at $200 \mathrm{rpm}$; (d) $\mathrm{CuS}$; (e) $\mathrm{CdS}$; (f) $\mathrm{As}_{2} \mathrm{~S}_{3}$ at $50 \mathrm{rpm}$.

A characterization of copper sulfide precipitates generated from a glycine-cyanide media was conducted, with an emphasis on the assessment of particle size distribution (PSD) under different conditions [56]. This study concluded that under the presence of divalent ions $\left(\mathrm{Ca}^{2+}\right.$ and $\left.\mathrm{Mg}^{2+}\right)$, large and fast-settling particle aggregates were generated. Even though there was no significant effect on aging, heating, and seeding on the PSD, more mature and crystalline copper sulfide precipitates were produced after aging, heating, or seeding. PSD were determined using laser diffraction (Mastersizer); however, this technique can be invasive to obtain the aggregates size in comparison to the results that can be obtained using non-invasive techniques to determine PSD. This can be done using an optical microscope with image analysis and processing [51], and through a focused beam reflectance measurement (FBRM) [54]. Both works studied the aggregate size distribution of copper sulfide generated from cyanide media, where a bi-modal behavior was found, which could not be observed with the conventional laser diffraction technique, probably due to the disaggregation effect promoted by the agitation. This fact implies that large aggregates of copper sulfide precipitates could be generated and facilitated by its hydrophobicity, although an important fraction would still remain disaggregated, which would potentially trigger settling difficulties due to their small size.

Additionally, the FBRM analysis showed that the aggregation capacity was lost at low copper concentration $(200 \mathrm{mg} / \mathrm{L})$. This result could be a consequence of: (i) the lower supersaturation achieved; or (ii) a possible sulfur layer formed by the oxidation of excess 
sulfide that avoided the particle aggregation [54]. Thus, the enhancement of the aggregation capacity of metal sulfide precipitates and the understanding of how small particles could be reduced will be a key aspect to improve the solid-liquid separation processes.

On another note, recent articles have conducted studies focused on the stability of $\mathrm{As}_{2} \mathrm{~S}_{3}$, taking into account that metal sulfide precipitation can efficiently remove arsenic from solutions in that form. The later step of disposal must consider the stability of this precipitate. A speciation analysis of the arsenic sulfide leaching showed that arsenic was first released into the aqueous phase as arsenite, and subsequently oxidized to arsenate. The extent of oxidation increased with an increase in $\mathrm{pH}$ value, dissolved oxygen, and temperature [93]. Due to the fact that the arsenic could tend to be released under atmospheric conditions, a thermally initiated copolymerization method using elemental sulfur was proposed [94]. The solidified compound showed low leachability, keeping an arsenic concentration in solution lower than $1.2 \mathrm{mg} / \mathrm{L}$ after 732 days of aging.

\section{Latest Breakthroughs in Solid-Liquid Separation}

As discussed in the previous section, the particle behavior of sulfide precipitates is determined by its hydrophilicity/hydrophobicity capacity, the ions contained in solution, the sulfide concentration, and $\mathrm{pH}$. This situation imposes high variability of the PSD that results from the reaction stage, increasing the uncertainty of solid-liquid separation performance. At an industrial scale, the current equipment used to separate precipitates are conventional gravitational clarifiers, as used, for example, in the SART process [3] and for the treatment of AMD [4]. Although these industrial applications have reported to be successful, they are still limited to the recovery of a few metals, mainly copper. Furthermore, there are several opportunities to improve these results, such as the size reduction, minimization of solid losses in the overflow, and the process control [95]. In this regard, there are critical studies that showed the fragility of the overall process of recovery with respect to a correct control of the clarifier, losing even $40 \%$ of copper recovery in this stage [96].

Studies to optimize the solid-liquid separation in metal sulfide precipitation processes are still emerging, although there are a few interesting examples which could address new research trends. The use of a magnetic field to modify the zeta potential of particles [97], the use of an abiological granular sludge [98], and the use of UV light irradiation to improve the aggregation [99] have been experiments conducted to enhance the settling rate of particles. In the first case, the application of a magnetic field of $2 \mathrm{~T}$ for $40 \mathrm{~min}$ increased the zeta potential from $-40 \mathrm{mV}$ to $16.5 \mathrm{mV}$. This result indicates that the aggregation of particles could increase after applying a magnetic field, but no PSD or settling test were performed [97]. In the second case, the use of an abiological granular sludge (ABGS) was used to improve the aggregation and settling of sulfide precipitates. Results showed that the use of an ABGS allowed for a settling velocity of $3.4 \mathrm{~m} / \mathrm{s}$ for $\mathrm{Zn} / \mathrm{Pb}$ precipitates from a real wastewater [98]. Finally, the third case showed that the particle size of CdS and a mix of CuS/CdS increased from 1-5 $\mu \mathrm{m}$ to $1000 \mu \mathrm{m}$ after $30 \mathrm{~min}$ of applying UV light irradiation. Moreover, the zeta potential increased between $120 \%$ and $150 \%$ for both types of sulfide precipitates [99]. Thus, the results of these studies are interesting to improve the settling rate of a gravitational clarification stage, although the industrial scaling-up and implementation could be challenging, particularly in the case of magnetic field or UV light irradiation applications.

In terms of the development of new solid-liquid separation processes or equipment, the gravitational lamella clarifiers have been conceptually proposed [100], but no data or results have been provided. A gravitational field-flow fractionation (GFFF) tank was proposed and designed using Computational Fluid Dynamics (CFD) simulations to fractionally separate $\mathrm{CuS}, \mathrm{ZnS}$, and $\mathrm{As}_{2} \mathrm{~S}_{3}$, obtaining interesting results to separate particles according to their size [101]. There were no validation studies of the model and design with experimental results. 
Recent applications of membrane filtration processes, specifically microfiltration (MF), to clarify copper sulfide precipitates produced in cyanide media [53] and AMD [20] have been reported (Figure 9). Furthermore, a mix of copper and zinc sulfide from a real cyanide solution of a gold mine was processed by MF [50]. Using feed pressure of slurries slower than 2 bar, flux values of 0.1 to $1.4 \mathrm{~L} / \mathrm{m}^{2} \mathrm{~s}$ were reached for copper sulfide and $\mathrm{Cu} / \mathrm{Zn}$ sulfides in cyanide media [50,53] and $0.1 \mathrm{~L} / \mathrm{m}^{2} \mathrm{~s}$ for copper sulfide in AMD [20]. The lowest flux for cyanide media was reached for a low copper concentration $(200 \mathrm{mg} / \mathrm{L})$ or under the presence of $\mathrm{Zn}$, a fact that in both cases can be explained by the small particle size generated in the reactor. These flux results meant a reduction in the residence time from 60-90 min to less than $5 \mathrm{~s}$ with respect to conventional gravitational clarifiers [53]. Consequently, there was also a reduction of $90 \%$ of equipment volume and around $30 \%$ of capex compared to conventional processes [50]. In the case of cyanide solutions, the use of membrane filtration processes also minimizes the emanations of $\mathrm{HCN}$ to the environment. Therefore, the use of this alternative process as a solid-liquid separation stage could not only support the overall recovery of the process, but it could also reduce the capital costs.

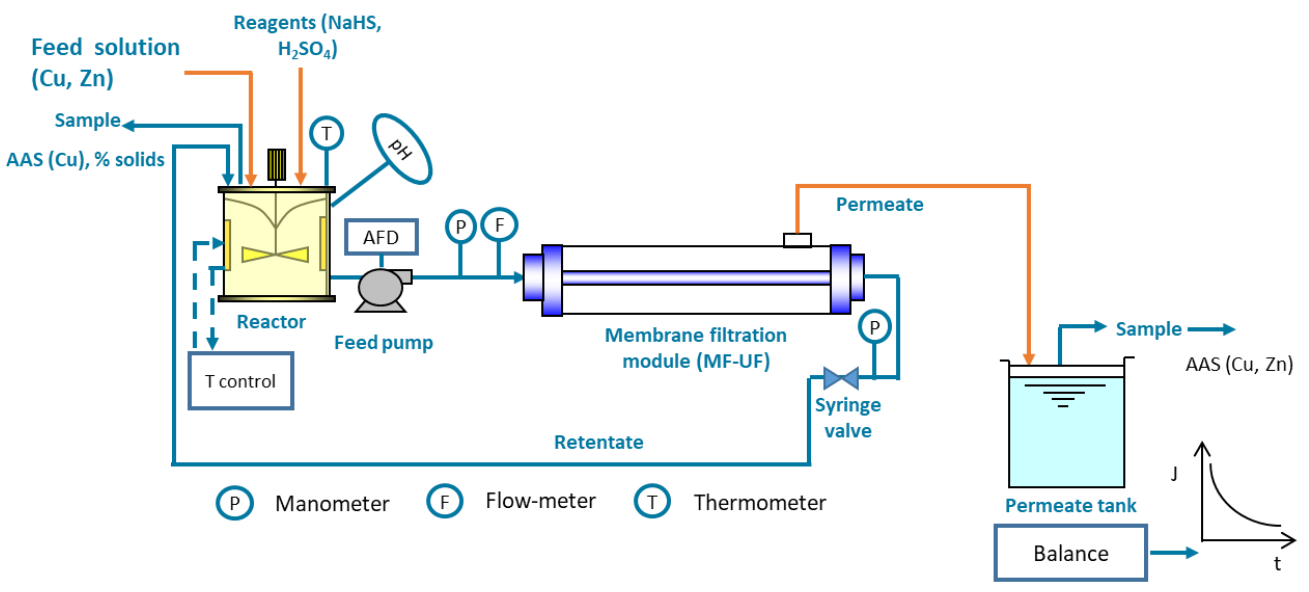

Figure 9. Membrane filtration prototype at a laboratory scale applied to assess metal sulfide precipitates in cyanide media and AMD. Adapted from [53].

\section{Future Perspectives}

Scientific and industrial applications of the metal sulfide precipitation process show that this it is a promising alternative to remove or recover potentially toxic elements (metals or metalloids) from different sources. Nevertheless, there are several gaps in our field, which are primarily due to a lack of understanding of this method with the aim of optimizing and expanding its application. This section summarizes an overview of challenges that should be addressed in further studies.

\subsection{Selective Precipitation and Recovery}

One of the main challenges is the control and establishment of the operational conditions required to advance towards the selective separation and recovery of highly pure metal sulfide precipitates from polymetallic sources, such as AMD, refinery wastewater, PLS, and others. The high variability of metal concentrations and their ranges present a challenge in terms of control. The control of $\mathrm{pH}$ and Eh, and $\mathrm{K}_{\mathrm{sp}}[22,48,52,67]$ are key variables to control a selective precipitation. These studies might support future methods for control strategies and the definition of the number of stages.

\subsection{Kinetic Studies}

This subject has been scarcely addressed, even when there are different studies showing long reaction times (see Table 3). Likewise, when $\mathrm{H}_{2} \mathrm{~S}$ gas is used, establishing the controlling stage of process velocity should be considered [70]. The first order model proposed by Yang and colleagues [71] was determined using a small quantity of experimental 
data and is limited to CuS. Through this process, the correct design of reactors should be based on proper kinetic models for each specific application.

\subsection{Reactor Type and Supersaturation Control}

Different reactor types that differ operationally from the conventional CSTR have been proposed, mainly focused on controlling the supersaturation $[26,71,74]$. The supersaturation control can promote the generation of precipitates with larger particle size to improve the solid-liquid separation [74]. However, recent studies show the relevance of the hydrophilicity/hydrophobicity capacity of metal sulfides [49,91,92], which demonstrate that the supersaturation control is not the unique variable that affects the PSD of precipitates. In fact, the aggregation time should be considered alongside with the reaction time when designing the reactor. The recent study performed by Barros and colleagues [54], using the FBRM, showed that the aggregation time was higher than the reaction time required to reach a maximum and stable particle size. Therefore, the optimal solid-liquid separation process strongly depends on the residence time defined for the reaction stage.

Novel methods to control the supersaturation, and also the sulfide consumption, could be conducted to advance in the development of new materials which could allow for the controlled release of sulfide [85].

\subsection{Solid-Liquid Separation}

During the last decade, several studies have tried to understand the behavior of precipitates to design an optimized solid-liquid separation stage. The main conclusions are that the aggregation behavior strongly depends on the hydrophilicity/hydrophobicity capacity of metal sulfides, affecting the resulting PSD during the precipitation [49,91,92]. However, the PSD curves of hydrophobic and highly aggregated precipitates, such as copper sulfide, show a bi-modal behavior, even containing up to $30 \%$ of particles smaller than $10 \mu \mathrm{m}[51,54]$. These fine particles can remain disaggregated due to the supersaturation condition or the formation of oxidized species on the particles' surface, diminishing the aggregation capacity [54]. The fine and colloidal particles can thereby be more exposed to the solution characteristics, such as $\mathrm{pH}$, sulfide concentration, or ionic strength $[16,86]$. Hence, a deeper understanding of the reaction conditions that define the PSD of precipitates will be necessary for each system in order to optimize the solid-liquid separation process.

The development of alternative unit operations for the conventional gravitational clarifiers could thus be an interesting route to limit the impact of precipitates' behavior, and, consequently, to reduce the equipment size and capital costs $[20,50,53]$.

\subsection{Stabilility of Precipitates for Disposal}

One interesting application of metal sulfide precipitation is the removal of arsenic from aqueous sources, particularly for the high content of arsenic in the $\mathrm{As}_{2} \mathrm{~S}_{3}$ precipitate. This application has been studied for AMD [5,6], industrial wastewater [26], and acidic wastewater generated from refineries $[40,42]$. Although the results obtained from these studies were promising, the stability of $\mathrm{As}_{2} \mathrm{~S}_{3}$ as a residue has been recently assessed $[93,102]$, and there are few studies proposing methods to stabilize this residue [40,94]. When the focus of the application of metal sulfide precipitation is the removal, supporting studies of metal/metalloids release will be required to ensure a safe disposal.

\subsection{Nanoparticle Production}

The use and application studies of metal sulfide nanoparticles (NPs) have increased in several fields, such as biomedicine, environmental remediation, agriculture, electronics, and catalytic reactions [60], as well as diverse applications such as surface coating, nanoswitches, solar cell components, radiation absorbers, photocatalysts, gas sensors, and dielectric filters [103]. Likewise, several routes for the synthesis of metal sulfide NPs have been proposed [104], even using ionic liquids [105]. In this context, there is an interesting opportunity to produce metal sulfide NPs directly from wastewaters or industrial solutions 
using a metal sulfide precipitation process. Until now, the main focus of the metal sulfide precipitation studies has been the recovery or removal of different metals/metalloids, without the possibility of enhancing the product value. A few studies have shown the promising possibility of producing NPs of CuS from AMD [15] or PdS from aqueous media [27], both directly using metal sulfide precipitation with biogenic sulfide as the sulfide source. Although these studies used synthetic and idealized solutions, there are several challenges remaining. For example, the optimization, control, definition of the number of stages, process integration options, and others. Future research must be developed to move forward in these interesting options.

In this article, we have discussed other aspects that should be taken into account in the production of NPs, such as the supersaturation control, the aggregation behavior (hydrophilicity/hydrophobicity) of precipitates, and the solid-liquid separation stage.

\section{Conclusions}

This study reviewed the recent progress made on the metal sulfide precipitation process, including its application on several sources to recover or remove different metals and/or metalloids. This method has demonstrated a great potential to treat wastewater, efficiently recovering valuable metals or removing potentially toxic elements (metals/ metalloids) and ensuring a low content of these elements in the effluent. Furthermore, the treatment of PLS from hydrometallurgical processes is a real alternative to conventional options. Moreover, the application has expanded to $\mathrm{Cu}, \mathrm{Zn}, \mathrm{Ni}, \mathrm{Cd}$ to Tl, As, $\mathrm{Pd}, \mathrm{Co}$, and Re. Research on this topic has also advanced in areas such as supersaturation control, new reactor types, and understanding the aggregation and colloidal behavior of precipitates. Some studies are highlighted, particularly those dealing with new materials containing a sulfide source to control the sulfide release during the reaction, and those that present the novel membrane filtration process as an alternative to conventional gravitational clarifiers for the solid-liquid separation stage. Finally, the possibility to produce metal sulfide NPs opens up an excellent opportunity to enhance the product value from the direct treatment of residue or from metallurgical plants.

Author Contributions: Conceptualization, H.E.; methodology, H.E., E.T. and L.B.; investigation, H.E., E.T. and L.B.; resources, H.E.; writing-original draft preparation, H.E., E.T. and L.B.; writingreview and editing, H.E. and E.T.; supervision, H.E.; project administration, H.E.; funding acquisition, H.E. All authors have read and agreed to the published version of the manuscript.

Funding: This research was funded by the National Commission for Scientific and Technological Research (CONICYT Chile) through the CONICYT-PIA Project AFB180004, CONICYT + FONDEF/ CONCURSO IDeA I + D FONDEF/CONICYT 2017 + ID17I20021. The APC was funded by MDPI.

Conflicts of Interest: The authors declare no conflict of interest. The funders had no role in the design of the study, in the collection, analyses, or interpretation of data in the writing of the manuscript, or in the decision to publish the results.

\section{References}

1. Lewis, A.E. Review of metal sulphide precipitation. Hydrometallurgy 2010, 104, 222-234. [CrossRef]

2. Monhemius, A.J. Precipitation diagrams for metal hydroxides, sulphides, arsenates and phosphates. Trans. Inst. Min. Metall. C 1977, 86, 202-206.

3. Estay, H. Designing the SART process-A review. Hydrometallurgy 2018, 176, 147-165. [CrossRef]

4. Kratochvil, D.; Ye, S.; López, O. Commercial Case Studies of Life Cycle Cost Reduction of ARD Treatment with Sulfide Precipitation. In Proceedings of the 10th International Conference on Acid Rock Drainage \& IMWA Annual Conference (10th ICARD IMWA 2015), Santiago, Chile, 21-24 April 2015. Available online: https://www.imwa.info/docs/imwa_2015/IMWA201 5_Kratochvi_020.pdf (accessed on 20 July 2021).

5. Altun, M.; Sahinkaya, E.; Durukan, I.; Bektas, S.; Komnitsas, K. Arsenic removal in a sulfidogenic fixed-bed column bioreactor. J. Hazard. Mater. 2014, 269, 31-37. [CrossRef] [PubMed]

6. Liu, R.; Yang, Z.; He, Z.; Wu, L.; Hu, C.; Wu, W.; Qu, J. Treatment of strongly acidic wastewater with high arsenic concentrations by ferrous sulfide (FeS): Inhibitive effects of S(0)-enriched surfaces. Chem. Eng. J. 2016, 304, 986-992. [CrossRef] 
7. Wang, H.; Chen, F.; Mu, S.; Zhang, D.; Pan, X.; Lee, D.; Chang, J. Removal of antimony (Sb(V)) from Sb mine drainage: Biological sulfate reduction and sulfide oxidation-precipitation. Bioresour. Technol. 2012, 146, 799-802. [CrossRef]

8. Xingyu, L.; Gang, Z.; Xiaoqiang, W.; Laichang, Z.; Jiankang, W.; Renman, R.; Dianzuo, W. A novel low pH sulfidogenic bioreactor using activated sludge as carbon source to treat acid mine drainage (AMD) and recovery metal sulfides: Pilot scale study. Miner. Eng. 2013, 48, 51-55. [CrossRef]

9. Macingova, E.; Luptakova, A. Recovery of Metals from Acid Mine Drainage. Chem. Eng. Trans. 2012, 28, 109-114. [CrossRef]

10. Zhang, W.; Honaker, R. Process development for the recovery of rare earth elements and critical metals from an acid mine leachate. Miner. Eng. 2020, 153, 106382. [CrossRef]

11. Ying, Z.; Zhijing, F.; Xiaofei, C.; Guoyan, Z. Bioremediation Process and Bioremoval Mechanism of Heavy Metal Ions in Acidic Mine Drainage. Chem. Res. Chin. Univ. 2018, 34, 33-38. [CrossRef]

12. Sun, R.; Li, Y.; Lin, N.; Ou, C.; Wang, X.; Zhang, L.; Jiang, F. Removal of heavy metals using a novel sulfidogenic AMD treatment system with sulfur reduction: Configuration, performance, critical parameters and economic analysis. Environ. Int. 2020, 136, 105457. [CrossRef]

13. Kumar, M.; Pakshirajan, K. Continuous removal and recovery of metals from wastewater using inverse fluidized bed sulfidogenic bioreactor. J. Clean. Prod. 2021, 284, 124769. [CrossRef]

14. Costa, J.M.; Rodriguez, R.P.; Sancinetti, G.P. Removal sulfate and metals $\mathrm{Fe}^{+2}, \mathrm{Cu}^{+2}$, and $\mathrm{Zn}^{+2}$ from acid mine drainage in an anaerobic sequential batch reactor. J. Environ. Chem. Eng. 2017, 5, 1985-1989. [CrossRef]

15. Colipai, C.; Southam, G.; Oyarzún, P.; González, D.; Díaz, V.; Contreras, B.; Nancucheo, I. Synthesis of Copper Sulfide Nanoparticles Using Biogenic $\mathrm{H}_{2} \mathrm{~S}$ Produced by a Low-pH Sulfidogenic Bioreactor. Minerals 2017, 8, 35. [CrossRef]

16. Mokone, T.P.; van Hille, R.P.; Lewis, A.E. Effect of solution chemistry on particle characteristics during metal sulfide precipitation. J. Colloid Interface Sci. 2010, 351, 10-18. [CrossRef]

17. Castro-Neto, E.S.; Aguiar, A.B.S.; Rodriguez, R.P.; Sancinetti, G.P. Acid mine drainage treatment and metal removal based on a biological sulfate reducing process. Braz. J. Chem. Eng. 2018, 35, 543-552. [CrossRef]

18. Sahinkaya, E.; Yucesoy, Z. Biotreatment of acidic zinc- and copper-containing wastewater using ethanol-fed sulfidogenic anaerobic baffled reactor. Bioprocess Biosyst. Eng. 2010, 33, 989-997. [CrossRef]

19. Leal-Gutiérrez, M.J.; Cuéllar-Briseño, R.; Castillo-Garduño, A.M.; Bernal-González, M.; Chávez-Castellanos, A.E.; Solís-Fuentes, J.A.; Durán-Domínguez-de-Bazúa, M.; Bazúa-Rueda, E.R. Precipitation of Heavy Metals Ions (Cu, Fe, Zn and Pb) from Mining Flotation Effluents Using a Laboratory-Scale Upflow Anaerobic Sludge Blanket Reactor. Water Air Soil Pollut. 2021, 197, 232. [CrossRef]

20. Menzel, K.; Barros, L.; García, A.; Ruby-Figueroa, R.; Estay, H. Metal sulfide precipitation coupled with membrane filtration process for recovering copper from acid mine drainage. Sep. Purif. Technol. 2021, 270, 118721. [CrossRef]

21. Li, H.; Zhang, H.; Long, J.; Zhang, P.; Chen, Y. Combined Fenton process and sulfide precipitation for removal of heavy metals from industrial wastewater: Bench and pilot scale studies focusing on in-depth thallium removal. Front. Environ. Sci. Eng. 2019, 13, 49. [CrossRef]

22. Wang, L.P.; Chen, Y.J. Sequential Precipitation of Iron, Copper, and Zinc from Wastewater for Metal Recovery. J. Environ. Eng. 2019, 145, 04018130. [CrossRef]

23. Janyasuthiwong, S.; Rene, E.R.; Esposito, G.; Lens, P.N.L. Effect of $\mathrm{pH}$ on $\mathrm{Cu}, \mathrm{Ni}$ and $\mathrm{Zn}$ removal by biogenic sulfide precipitation in an inversed fluidized bed bioreactor. Hydrometallurgy 2015, 158, 94-100. [CrossRef]

24. Bilgin, A.; Jaffé, P.R. Precipitation of Copper (II) in a Two-Stage Continuous Treatment System Using Sulfate Reducing Bacteria. Waste Biomass Valorization 2018, 10, 2907-2914. [CrossRef]

25. De Alburquerque, V.F.; de Barros, A.L.; Lopes, A.C.; dos Santos, A.B.; do Nascimento, R.F. Removal of the metal ions $\mathrm{Zn}^{2+}, \mathrm{Ni}^{2+}$ and $\mathrm{Cu}^{2+}$ by biogenic sulfide in UASB reactor and speciation studies. Desalination Water Treat. 2013, 51, 2093-2101. [CrossRef]

26. Guo, L.; Du, Y.; Yi, Q.; Li, D.; Cao, L.; Du, D. Efficient removal of arsenic from "dirty acid" wastewater by using a novel immersed multi-start distributor for sulphide feeding. Sep. Purif. Technol. 2015, 142, 209-214. [CrossRef]

27. Nanusha, M.Y.; Carlier, J.D.; Carvalho, G.I.; Costa, M.C.; Paiva, A.P. Separation and recovery of Pd and Fe as nanosized metal sulphides by combining solvent extraction with biological strategies based on the use of sulphate-reducing bacteria. Sep. Purif. Technol. 2019, 212, 747-756. [CrossRef]

28. Yatim, S.R.M.; Zainuddin, N.A.; Mokhtar, N.S.; Syahjidan, H.N.; Kamsuri, S.N.H. Competitiveness in removing copper, zinc and chromium trivalent in plating industrial effluent by using hydroxide precipitation versus sulphide precipitation. IOP Conf. Ser. Mater. Sci. Eng. 2021, 1053, 012084. [CrossRef]

29. Fang, D.; Zhang, R.; Deng, W.; Li, J. Highly efficient removal of Cu(II), Zn(II), Ni(II) and Fe(II) from electroplating wastewater using sulphide from sulphidogenic bioreactor effluent. Environ. Technol. 2012, 33, 1709-1715. [CrossRef] [PubMed]

30. Zainuddin, N.A.; Mamat, T.A.R.; Maarof, H.I.; Puasa, S.W.; Yatim, S.R.M. Removal of Nickel, Zinc and Copper from Plating Process Industrial Raw Effluent Via Hydroxide Precipitation Versus Sulphide Precipitation. IOP Conf. Ser. Mater. Sci. Eng. 2019, 551, 012122. [CrossRef]

31. Li, G.; Liang, Z.; Sun, J.; Qiu, Y.; Qiu, C.; Liang, X.; Zhu, Y.; Wang, P.; Li, Y.; Jiang, F. A pilot-scale sulfur-based sulfidogenic system for the treatment of $\mathrm{Cu}$-laden electroplating wastewater using real domestic sewage as electron donor. Water Res. 2021, 195, 116999. [CrossRef] 
32. Hamza, M.F.; Roux, J.C.; Guibal, E. Metal valorization from the waste produced in the manufacturing of Co/Mo catalysts: Leaching and selective precipitation. J. Mater. Cycles Waste Manag. 2019, 21, 525-538. [CrossRef]

33. Vemic, M.; Bordas, F.; Comte, S.; Guibaud, G.; Lens, P.N.L.; van Hullebusch, E.D. Recovery of molybdenum, nickel and cobalt by precipitation from the acidic leachate of a mineral sludge. Environ. Technol. 2016, 37, 2231-2242. [CrossRef]

34. Park, I.; Kim, D.; Kim, M.; Jeong, H. Recovery of Cadmium in Nickel-Cadmium Leaching Solution by Sulfide Precipitation Method. J. Korean Inst. Met. Mater. 2019, 57, 726-731. [CrossRef]

35. Li, H.; Oraby, E.; Eksteen, J. Recovery of copper and the deportment of other base metals from alkaline glycine leachates derived from printed circuit boards (WPCBs). Hydrometallurgy 2021, 199, 105540. [CrossRef]

36. Innocenzi, V.; De Michelis, I.; Ferella, F.; Beolchini, F.; Kopacek, B.; Vegliò, F. Recovery of yttrium from fluorescent powder of cathode ray tube, CRT: Zn removal by sulphide precipitation. Waste Manag. 2013, 33, 2364-2371. [CrossRef] [PubMed]

37. Cibati, A.; Cheng, K.Y.; Morris, C.; Ginige, M.P.; Sahinkaya, E.; Pagnanelli, F.; Kaksonen, A.H. Selective precipitation of metals from synthetic spent refinery catalyst leach liquor with biogenic $\mathrm{H}_{2} \mathrm{~S}$ produced in a lactate-fed anaerobic baffled reactor. Hydrometallurgy 2013, 139, 154-161. [CrossRef]

38. Choubey, P.K.; Dinkar, O.S.; Panda, R.; Kumari, A.; Jha, M.K.; Pathak, D.D. Selective extraction and separation of Li, Co and Mn from leach liquor of discarded lithium ion batteries (LIBs). Waste Manag. 2021, 121, 452-457. [CrossRef]

39. Calvert, G.; Kaksonen, A.H.; Cheng, K.Y.; Van Yken, J.; Chang, B.; Boxall, N.J. Recovery of Metals from Waste Lithium Ion Battery Leachates Using Biogenic Hydrogen Sulfide. Minerals 2019, 9, 563. [CrossRef]

40. Hu, B.; Yang, T.; Liu, W.; Zhang, D.; Chen, L. Removal of arsenic from acid wastewater via sulfide precipitation and its hydrothermal mineralization stabilization. Trans. Nonferrous Met. Soc. China 2019, 29, 2411-2421. [CrossRef]

41. Zhang, Y.; Feng, X.; Jin, B. An effective separation process of arsenic, lead, and zinc from high arsenic-containing copper smelting ashes by alkali leaching followed by sulfide precipitation. Waste Manag. Res. 2020, 38, 1214-1221. [CrossRef]

42. Hong, T.; Zheng, T.; Liu, M.; Mumford, K.A.; Stevens, G.W. Investigation on the recovery of rhenium in the high arsenite wash acid solution from the copper smelting process using reducing sulfide precipitation method. Hydrometallurgy 2020, 195, 105402. [CrossRef]

43. Zhang, X.; Tian, J.; Hu, Y.; Han, H.; Luo, X.; Sun, W.; Yue, T.; Wang, L.; Cao, X.; Zhou, H. Selective sulfide precipitation of copper ions from arsenic wastewater using monoclinic pyrrhotite. Sci. Total Environ. 2020, 705, 135816. [CrossRef] [PubMed]

44. Cai, X.; Kong, L.; Hu, X.; Peng, X. Recovery of Re(VII) from strongly acidic wastewater using sulphide: Acceleration by UV irradiation and the underlying mechanism. J. Hazard. Mater. 2021, 416, 126233. [CrossRef] [PubMed]

45. Hedrich, S.; Kermer, R.; Aubel, T.; Martin, M.; Schippers, A.; Johnson, D.B.; Janneck, E. Implementation of biological and chemical techniques to recover metals from copper-rich leach solutions. Hydrometallurgy 2018, 179, 274-281. [CrossRef]

46. Chen, T.; Lei, C.; Yan, B.; Xiao, X. Metal recovery from the copper sulfide tailing with leaching and fractional precipitation technology. Hydrometallurgy 2014, 147-148, 178-182. [CrossRef]

47. Ye, M.; Li, G.; Yan, P.; Ren, J.; Zheng, L.; Han, D.; Sun, S.; Huang, S.; Zhong, Y. Removal of metals from lead-zinc mine tailings using bioleaching and followed by sulfide precipitation. Chemosphere 2017, 185, 1189-1196. [CrossRef] [PubMed]

48. Liu, W.; Sun, B.; Zhang, D.; Chen, L.; Yang, T. Selective Separation of Similar Metals in Chloride Solution by Sulfide Precipitation Under Controlled Potential. JOM 2017, 69, 2358-2363. [CrossRef]

49. Gim-Krumm, M.; Quilaqueo, M.; Rojas, V.; Seriche, G.; Ruby-Figueroa, R.; Cortés-Arriagada, D.; Romero, J.; Troncoso, E.; Estay, $\mathrm{H}$. Impact of precipitate characteristics and precipitation conditions on the settling performance of a sulfide precipitation process: An exhaustive characterization of the aggregation behavior. Hydrometallurgy 2019, 189, 105150. [CrossRef]

50. Estay, H.; Ruby-Figueroa, R.; Quilaqueo, M.; Seriche, G.; Cortés, I.; Gim-Krumm, M.; Barros, L. Enhancing the effectiveness of copper and cyanide recovery in gold cyanidation: A new integrated membrane process. Hydrometallurgy 2021, 202, 105606. [CrossRef]

51. Quilaqueo, M.; Gim-Krumm, M.; Ruby-Figueroa, R.; Troncoso, E.; Estay, H. Determination of size distribution of precipitation aggregates using non-invasive microscopy and semiautomated image processing and analysis. Minerals 2019, 9, 724. [CrossRef]

52. Estay, H.; Gim-Krumm, M.; Seriche, G.; Quilaqueo, M.; Barros, L.; Ruby-Figueroa, R.; Romero, J.; Troncoso, E. Optimizing the SART process: A critical assessment of its design criteria. Miner. Eng. 2020, 146, 106116. [CrossRef]

53. Estay, H.; Ruby-Figueroa, R.; Gim-Krumm, M.; Seriche, G.; Quilaqueo, M.; Díaz-Quezada, S.; Cortés, I.; Barros, L. Changing the conventional clarification method in metal sulfide precipitation by a membrane-based filtration process. J. Mater. Sci. Technol. 2021, 11, 693-709. [CrossRef]

54. Barros, L.; Gim-Krumm, M.; Seriche, G.; Quilaqueo, M.; Castillo, C.; Ihle, C.F.; Ruby- Figueroa, R.; Estay, H. In-situ and real-time aggregation size evolution of copper sulfide precipitates using focused beam reflectance measurement (FBRM). Powder Technol. 2021, 380, 205-218. [CrossRef]

55. Deng, Z.; Oraby, E.A.; Eksteen, J.J. The sulfide precipitation behaviour of $\mathrm{Cu}$ and Au from their aqueous alkaline glycinate and cyanide complexes. Sep. Purif. Technol. 2019, 218, 181-190. [CrossRef]

56. Deng, Z.; Oraby, E.A.; Eksteen, J.J. Sulfide precipitation of copper from alkaline glycine-cyanide solutions: Precipitate characterisation. Miner. Eng. 2020, 145, 106102. [CrossRef]

57. Naidu, G.; Ryu, S.; Thiruvenkatachari, R.; Choi, Y.; Jeong, S.; Vigneswaran, S. A critical review on remediation, reuse, and resource recovery from acid mine drainage. Environ. Pollut. 2019, 247, 1110-1124. [CrossRef] [PubMed] 
58. Sánchez-Andrea, I.; Sanz, J.L.; Bijmans, M.F.M.; Stams, A.J.M. Sulfate reduction at low pH to remediate acid mine drainage. J. Hazard. Mater. 2014, 269, 98-109. [CrossRef] [PubMed]

59. Papirio, S.; Villa-Gomez, D.K.; Esposito, G.; Pirozzi, F.; Lens, P.N.L. Acid mine drainage treatment in fluidized-bed bioreactors by sulfate-reducing bacteria: A critical review. Crit. Rev. Environ. Sci. Technol. 2013, 43, 2545-2580. [CrossRef]

60. Kumar, M.; Nandi, M.; Pakshirajan, K. Recent advances in heavy metal recovery from wastewater by biogenic sulfide precipitation. J. Environ. Manag. 2021, 278, 111555. [CrossRef]

61. Alam, R.; McPhedran, K. Applications of biological sulfate reduction for remediation of arsenic-A review. Chemosphere 2019, 222, 932-944. [CrossRef]

62. Diez-Ercilla, M.; Sánchez-España, J.; Yusta, I.; Wendt-Potthoff, K.; Koschorreck, M. Formation of biogenic sulphides in the water column of an acidic pit lake: Biogeochemical controls and effects on trace metal dynamics. Biogeochemistry 2014, 121, 519-536. [CrossRef]

63. Sethurajan, M.; Gaydardzhiev, S. Bioprocessing of spent lithium ion batteries for critical metals recovery-A review. Resour. Conserv. Recycl. 2021, 165, 105225. [CrossRef]

64. Hedjazi, F.; Monhemius, A.J. Copper-gold ore processing with ion exchange and SART technology. Miner. Eng. 2014, 64, 120-125. [CrossRef]

65. Estay, H.; Gim-Krumm, M.; Quilaqueo, M. Two-stage SART process: A feasible alternative for gold cyanidation plants with high zinc and copper contents. Minerals 2018, 8, 392. [CrossRef]

66. Medina, D.; Anderson, C.G. A review of the cyanidation treatment of copper-gold ores and concentrates. Metals 2020, $10,897$. [CrossRef]

67. Uçar, D. Sequential Precipitation of Heavy Metals Using Sulfide-Laden Bioreactor Effluent in a pH Controlled System. Miner. Process. Extr. Metall. Rev. 2017, 38, 162-167. [CrossRef]

68. Ostermeyer, P.; Bonin, L.; Folens, K.; Verbruggen, F.; García-Timermans, C.; Verbeken, K.; Rabaey, K.; Hennebel, T. Effect of speciation and composition on the kinetics and precipitation of arsenic sulfide from industrial metallurgical wastewater. J. Hazard. Mater. 2021, 409, 124418. [CrossRef] [PubMed]

69. Gharabaghi, M.; Irannajad, M.; Azadmehr, A.R. Selective Sulphide Precipitation of Heavy Metals from Acidic Polymetallic Aqueous Solution by Thioacetamide. Ind. Eng. Chem. Res. 2012, 51, 954-963. [CrossRef]

70. Tokuda, H.; Kuchar, D.; Mihara, N.; Kubota, M.; Matsuda, H.; Fukuta, T. Study on reaction kinetics and selective precipitation of $\mathrm{Cu}, \mathrm{Zn}, \mathrm{Ni}$ and $\mathrm{Sn}$ with $\mathrm{H}_{2} \mathrm{~S}$ in single-metal and multi-metal systems. Chemosphere 2008, 73, 1448-1452. [CrossRef] [PubMed]

71. Yang, Z.; Li, B.; Zeng, W.; Li, K.; Liu, S.; Hu, H.; Guo, W. Design and analysis of continuous-flow reactors for copper sulfide precipitation process by a computational method. Environ. Sci. Pollut. Res. 2019, 26, 34531-34551. [CrossRef]

72. Simons, A. Fundamental Study of Copper and Cyanide Recovery from Gold Tailing by Sulfidisation. Ph.D. Thesis, WA School of Mines, Curtin University, Perth, WA, USA, 2015.

73. Van Hille, R.P.; Peterson, K.A.; Lewis, A.E. Copper sulphide precipitation in a fluidised bed reactor. Chem. Eng. Sci. 2005, 60, 2571-2578. [CrossRef]

74. Mokone, T.P.; van Hille, R.P.; Lewis, A.E. Metal sulphides from wastewater: Assessing the impact of supersaturation control strategies. Water Res. 2012, 46, 2088-2100. [CrossRef]

75. Villa-Gomez, D.; Ababneh, H.; Papirio, S.; Rousseau, D.P.L.; Lens, P.N.L. Effect of sulfide concentration on the location of the metal precipitates in inversed fluidized bed reactors. J. Hazard. Mater. 2011, 192, 200-207. [CrossRef]

76. Kaksonen, A.H.; Riekkola-Vanhanen, M.L.; Puhakka, J.A. Optimization of metal sulphide precipitation in fluidized-bed treatment of acidic wastewater. Water Res. 2003, 37, 255-266. [CrossRef]

77. Sampaio, R.M.M.; Timmers, R.A.; Kocks, N.; André, V.; Duarte, M.T.; van Hullebusch, E.D.; Farges, F.; Lens, P.N.L. Zn-Ni sulfide selective precipitation: The role of supersaturation. Sep. Purif. Technol. 2010, 74, 108-118. [CrossRef]

78. Zeng, W.; Guo, W.; Li, B.; Wei, Z.; Dionysiou, D.D.; Xiao, R. Kinetics and mechanistic aspects of removal of heavy metal through gas-liquid sulfide precipitation: A computational and experimental study. J. Hazard. Mater. 2021, 408, 124868. [CrossRef] [PubMed]

79. Kiran, M.G.; Pakshirajan, K.; Das, G. An overview of sulfidogenic biological reactors for the simultaneous treatment of sulfate and heavy metal rich wastewater. Chem. Eng. Sci. 2017, 158, 606-620. [CrossRef]

80. Silva, P.M.O.; Raulino, G.S.C.; Vidal, C.B.; do Nascimento, R.F. Selective precipitation of $\mathrm{Cu}^{2+}, \mathrm{Zn}^{2+}$ and Ni ${ }^{2+}$ ions using $\mathrm{H}_{2} \mathrm{~S}(\mathrm{~g})$ produced by hydrolysis of thioacetamide as the precipitating agent. Desalination Water Treat. 2017, 95, 220-226. [CrossRef]

81. Rostamnezhad, N.; Kahforoushan, D.; Sahraei, E.; Ghanbarian, S.; Shabani, M. A method for the removal of Cu(II) from aqueous solutions by sulfide precipitation employing heavy oil fly ash. Desalination Water Treat. 2016, 57, 17593-17602. [CrossRef]

82. Zvimba, J.N.; Mulopo, J.; de Beer, M.; Bologo, L.; Mashego, M. The dissolution characteristics of calcium sulfide and utilization as a precipitation agent in acidic wastewater effluent treatment. Water Sci. Techonol. 2011, 63, 2860-2866. [CrossRef]

83. Hong, T.; Wei, Y.; Li, L.; Mumford, K.; Stevens, G. An investigation into the precipitation of copper sulfide from acidic sulfate solutions. Hydrometallurgy 2020, 192, 105288. [CrossRef]

84. Zhou, Y.; Liu, Z.; Bo, A.; Tana, T.; Liu, X.; Zhao, F.; Sarina, S.; Jia, M.; Yang, C.; Gu, Y.; et al. Simultaneous removal of cationic and anionic heavy metal contaminants from electroplating effluent by hydrotalcite adsorbent with disulfide $\left(\mathrm{S}^{2-}\right)$ intercalation. $J$. Hazard. Mater. 2020, 382, 121111. [CrossRef] 
85. Zhu, F.; Hu, X.; Kong, L.; Peng, X. Calcium sulfide-organosilicon complex for sustained release of $\mathrm{H}_{2} \mathrm{~S}$ in strongly acidic wastewater: Synthesis, mechanism and efficiency. J. Hazard. Mater. 2021, 421, 126745. [CrossRef]

86. Mokone, T.P.; Lewis, A.E.; van Hille, R.P. Effect of post-precipitation conditions on surface properties of colloidal metal sulphide precipitates. Hydrometallurgy 2012, 119-120, 55-66. [CrossRef]

87. Nduna, M.; Rodriguez-Pascual, M.; Lewis, A.E. Effect of dissolved precipitating ions on the settling characteristics of copper sulphide. J. South. Afr. Inst. Min. Metall. 2013, 113, 435-439. Available online: http://www.scielo.org.za/scielo.php?script=sci_ arttext\&pid=S2225-62532013000500009\&lng=en\&nrm=iso (accessed on 20 August 2021).

88. Chen, Q.; Yao, Y.; Li, X.; Lu, J.; Zhou, J.; Huang, Z. Comparison of heavy metal removals from aqueous solutions by chemical precipitation and characteristics of precipitates. J. Water Process Eng. 2018, 26, 289-300. [CrossRef]

89. Nduna, M.K.; Lewis, A.E.; Nortier, P. A model for the zeta potential of copper sulphide. Colloids Surface A 2014, 441, 643-652. [CrossRef]

90. Villa-Gomez, D.K.; van Hullebusch, E.D.; Maestro, R.; Farges, F.; Nikitenko, S.; Kramer, H.; Gonzalez-Gil, G.; Lens, P.N.L. Morphology, Mineralogy, and Solid-Liquid Phase Separation Characteristics of $\mathrm{Cu}$ and Zn Precipitates Produced with Biogenic Sulfide. Environ. Sci. Technol. 2014, 48, 664-673. [CrossRef] [PubMed]

91. Wrighton-Araneda, K.; Ruby-Figueroa, R.; Estay, H.; Cortés-Arriagada, D. Interaction of $\mathrm{H}_{2} \mathrm{O}$ with $(\mathrm{CuS}) \mathrm{n},(\mathrm{Cu} 2 \mathrm{~S}) \mathrm{n}$, and $(\mathrm{ZnS}) \mathrm{n}$ small clusters $(n=1-4,6)$ : Relation to the aggregation characteristics of metal sulfides at aqueous solutions. J. Mol. Model. 2019, 25, 291. [CrossRef]

92. Xia, Z.; Peng, X.; Kong, L.; Hu, X. Hydrophilicity/hydrophobicity of metal sulfide particles as a determinator of aggregation performance in wastewater. J. Water Process Eng. 2021, 40, 101900. [CrossRef]

93. Mirazimi, M.; Liu, W. Aqueous arsenic and sulfur speciation analysis and solid phase characterization in the dissolution of arsenic trisulfide. Hydrometallurgy 2021, 199, 105545. [CrossRef]

94. Kong, L.; Xia, Z.; Hu, X.; Peng, X. Chemical solidification/stabilization of arsenic sulfide and oxide mixed wastes using elemental sulfur: Efficiencies, mechanisms and long-term stabilization enhancement by dicyclopentadiene. J. Hazard. Mater. 2021, 419, 126390. [CrossRef]

95. Breuer, P. Dealing with copper in gold ores; implemented and future approaches. In Proceedings of the Gold-PM Conference, 20th Anniversary Event, ALTA 2015, Perth, Australia, 23-30 May 2015.

96. Estay, H.; Carvajal, P.; Hedjazi, F.; Van Zeller, T. The SART process experience in the Gedabek plant. In Proceedings of the Hydroprocess 2012, 4th International Workshop on Process Hydrometallurgy, Santiago, Chile, 11-13 July 2012.

97. Gqebe, S.; Rodriguez-Pascual, M.; Lewis, A. A modification of the zeta potential of copper sulphide by the application of a magnetic field in order to improve particle settling. J. South. Afr. Inst. Min. Metall. 2016, 116, 575-580. [CrossRef]

98. Yan, X.; Chai, L.; Li, Q.; Ye, L.; Yang, B.; Wang, Q. Abiological Granular Sludge Formation Benefit for Heavy Metal Wastewater Treatment Using Sulfide Precipitation. Clean-Soil Air Water 2017, 45, 1500730. [CrossRef]

99. Peng, X.; Xia, Z.; Kong, L.; Hu, X.; Wang, X. UV light irradiation improves the aggregation and settling performance of metal sulfide particles in strongly acidic wastewater. Water Res. 2019, 163, 114860. [CrossRef] [PubMed]

100. Shammas, N.K.; Wang, L.K. Sulfide Precipitation for Treatment of Metal Wastes. In Handbook of Advanced Industrial and Hazardous Waste Management; Wang, L.K., Wang, M.H.S., Hung, Y.T., Shammas, N.K., Chen, J.P., Eds.; CRC Press, Taylor \& Francis Group: Boca Raton, FL, USA, 2018; pp. 185-238.

101. Zeng, W.; Guo, W.; Li, B.; Xiao, R.; Hu, H.; Yan, Y.; Wu, L.; Wei, Z.; Chai, L. Experimental and simulation studies of metal sulfide precipitates separation in copper smelting waste acid using a gravitation field-flow fractionation method. J. Water Process Eng. 2020, 36, 101330. [CrossRef]

102. Mirazimi, M.; Fan, J.; Liu, W. Kinetics of arsenic and sulfur release from amorphous arsenic trisulfide. Hydrometallurgy 2021, 200, 105555. [CrossRef]

103. Da Costa, J.P.; Girão, A.V.; Trindade, T.; Costa, M.C.; Duarte, A.; Rocha-Santos, T. Biological synthesis of nanosized sulfide semiconductors: Current status and future prospects. Appl. Microbiol. Biotechnol. 2016, 100, 8283-8302. [CrossRef]

104. Balakrishnan, A.; Groeneveld, J.D.; Pokhrel, S.; Mädler, L. Metal Sulfide Nanoparticles: Precusor Chemistry. Chem. Eur. J. 2021, 27, 6390-6406. [CrossRef] [PubMed]

105. Balischewski, C.; Choi, H.S.; Behrens, K.; Beqiraj, A.; Körzdörfer, T.; Gebner, A.; Wendel, A. Metal Sulfide Nanoparticle Synthesis with Ionic Liquids-State of the Art and Future Perspectives. ChemistryOpen 2021, 10, 272-295. [CrossRef] 